\title{
Geostatistics and Spatial Analysis of Groundwater Hydrochemistry near Leliefontein in the Northern Cape, South Africa
}

\author{
Adadzi Patrick Cudjoe ${ }^{1}$ \\ 1 Institute for Groundwater Studies, Faculty of Natural and Agricultural Sciences, University of the Free State, \\ Bloemfontein 9300, South Africa \\ e-mail: 2018425096@ufs4life.ac.za
}

\begin{abstract}
The fractured groundwater aquifers, predominantly found in South Africa, show varying groundwater chemical characteristics in various locations. The hydrochemistry of groundwater is affected by the weathering of rock formations in contact and anthropogenic activities. Determination of groundwater chemistry is important for aquifer protection and overall groundwater management. A hydrochemical analysis is a useful tool for identification of water types, chemical composition, its suitability for specified purposes, and an important requirement for water use licensing applications. The hydrochemical data of groundwater from 79 boreholes near Leliefontein, Kamiesberg local municipality of South Africa, were analysed, using integrated statistical, geostatistics and spatial interpolation methods. The result shows $\mathrm{Na}+$ and $\mathrm{Cl}^{-}$to be the abundant cation and anion. The mean concentration of $\mathrm{Na}$ at Leliefontein was $267.39 \mathrm{mg} / \mathrm{l}$, and that of $\mathrm{Cl}$ was $574.81 \mathrm{mg} / \mathrm{l}$. The ionic concentrations in groundwater was in sequence of $\mathrm{Cl}^{-}>\mathrm{Na}^{+}>\mathrm{HCO}_{3}^{-}>\mathrm{SO}_{4}{ }^{2-}>\mathrm{Ca}^{2+}>\mathrm{Mg}^{2+}>\mathrm{NO}_{3}^{-}>\mathrm{Si}>\mathrm{K}^{+}>\mathrm{F}^{-}$. The analysis indicated that the cation exchanges in groundwater are influenced by limited silicate weathering, with calcite and dolomite dissolution. Geostatistical and spatial analysis interpolation for the major cation $(\mathrm{Na})$ and major anion $(\mathrm{Cl})$, Sodium Adsorption Ratio (SAR), Electrical Conductivity (EC) and Water Quality Index (WQI) was performed using Inverse Distance Weighing method. The hydrochemical data for the Leliefontein groundwater were analysed to classify water for domestic use (drinking) and agriculture (irrigation) purposes, based on the recommended guidelines of the South African National Standard (SANS). The study area was characterised by high salinity of three water types, viz, $\mathrm{Na}-\mathrm{Cl}$ seawater type, $\mathrm{Ca}-\mathrm{Cl}$ reverse ion-exchange water type, and $\mathrm{Na}-\mathrm{HCO}_{3}$ base ion-exchange water types. About $70-80 \%$ of the boreholes in Leliefontein met the requirement for irrigation application for Sodium Adsorption Ratio (SAR) and salinity hazard analysis, while the groundwater generally required further treatment before domestic use.
\end{abstract}

Keywords: groundwater, hydrochemistry, geostatistics, spatial analysis, water quality

\section{INTRODUCTION}

The groundwater resources are an intrinsic part of the water resources of South Africa. It provides a substantially more significant portion of the water requirements for household consumption and agricultural activities: Agriculture - 62\%, Rural and urban household use - 27\%, Mining and industrial use $-6 \%$, Afforestation $-3 \%$, Power generation - $2 \%$ (SSA, 2016). In South Africa, domestic, industrial, and agricultural demands for water is unsustainable without the groundwater resources. It is, therefore, necessary to classify groundwater in terms of suitability for various purposes for equitable utilisation. The South Africa's surface water resources are unequally distributed and incapable of sustaining the demand for all sectors on the economy (Bredenhann \& Braune, 2000). For decision-makers on policy, uses, and protection of groundwater resources to equitably manage groundwater, the prerequisite is to comprehend the quality and the quantity of the groundwater resources available. The groundwater quality analysis and interpretation in a necessary scientific tool for ensuring sustainable management without compromising future demands.

The observed variations in the hydrochemical profile of groundwater from one location to 
another are attributed to climatic, seasonal, geological, and anthropogenic variabilities (JonchClausen, 2004). Groundwater chemistry changes from one place to the other and is controlled by the geological formations through which it flows. The chemistry of water determines the quality of all water resources including groundwater and therefore, the analysis and assessment of groundwater chemistry are essential for quality assessment and pollution control. Population increases have placed increasing demands on the surface water and groundwater resources in South Africa and throughout the world. The hydrochemical data analysis reveals the appropriateness of groundwater resources different purposes (Sadashivaiah et al., 2008).

Groundwater at specific locations is also influenced by such factors as climate, soil and land use, lithology, geological structures, and surface water bodies [Stallard \& Edmond, 1983; Subba Rao, 2002). Water type and geochemical evaluation are beneficial as a preliminary assessment tool for understanding the complex subsurface hydrogeochemical processes. Over the years, scientists have used various theories and techniques in the pursuit of water chemistry, groundwater chemistry, and hydrogeochemical processes (Hill, 1940; Piper, 1944; Durov, 1948; Stiff, 1951; Garrel, 1967; Miller, 1991, Kimblin, 1995; Mayo \& Loucks, 1995; Hudson \& Golding, 1997).

The application of statistical methods to groundwater hydrochemistry data is influenced by the type of data and the data characteristics. Statistical methods should be based on the scientific process of inductive and deductive modelling. Many studies in which the application of statistical analysis are based on wrong assumptions of data characteristics, result in the production of incorrect and inconclusive interpretations. Geostatistical methods are a subcategory, which is uniquely applicable to geographical data analysis and interpretation (Goovaerts, 1997). It is a scientific method used mainly for spatial data analysis (Cressie, 1993; Bolstad, 2008). Currently, the integration of geostatistics and GIS data is a useful method to explore spatial data analysis, ground data, remote sensing, improving DEM generation and for simulations (Hengl et al., 1983; Kyriakidis et al., 1999; Atkinson \& Quattrochi, 2000; Brus \& Heuvelink, 2007; Atkinson \& Quattrochi, 2000). The geostatistical methods are widely applied in the fields of water resources, geosciences, environmental sciences, meteorology, mathematics and statistics, agriculture and soil sciences, civil engineering, ecology, and petroleum engineering (Zhou et al., 2007; Hengl et al., 2009a). Spatial interpolation is aimed at the prediction of unknown values of a parameter over an area of concern which is then used for generating an image map (Lam, 1983; Mitas \& Mitasova, 1999; Dubois \& Galmarini, 2004). The heostatistical application mapping involves prediction based on the quantitative and statistical methods.

The use of groundwater resources requires a thorough investigation to ensure that it is free from contamination and conforms to the standard requirements for specified utilisation. The integrated application of statistical, geostatistics and spatial analysis methods essentially helps to understand and interpret the water types and composition similarities. The integrated assessment approach to hydrogeochemical analysis is an effective groundwater resource management technique.

\section{DATA AND METHODOLOGY}

\section{Location of study area}

Leliefontein is located in the Namakwa District Municipality in the Northern Cape of South Africa (Figure 1), east of Namaqua National Park and Skilpad Nature Reserve and between longitude $17^{\circ} 52^{\prime} 38.42^{\prime \prime}-18^{\circ} 29^{\prime} 47.31^{\prime \prime} \mathrm{E}$ and latitude $30^{\circ} 18.40^{\prime} 744^{\prime \prime}-30^{\circ} 18^{\prime} 56.45^{\prime \prime} \mathrm{S}$ with altitudes of 700 to $1195 \mathrm{~m}$ a.s.l. The study area is within the Bushmanland subprovince with topography slopes is mostly of uniform elevation. The arid climatic condition of intense heat produces high evaporative rates within the region. The mean annual temperature is $17.4^{\circ} \mathrm{C}$, mean annual precipitation is between $20 \mathrm{~mm}$ to $300 \mathrm{~mm}$, and mean yearly evaporation is between $2000 \mathrm{~mm}$ to 2350 $\mathrm{mm}$. The land in the study area is predominantly used for the crop, horticulture, and animal production. The Buffels River in the Northern cape flows through the Kamies mountain and discharges into the Atlantic Ocean.

The Leliefontein basement aquifers are made of fractured bedrocks and weathered regolith, with linear system structurally controlled by faults. The groundwater in the region is relatively saline, with high salt contents. The high salt concentration in groundwater is also attributed to the aquifer system lithology and the high evaporation rates of the region (Pietersen et al., 2009; Benito et al., 2010; Adams et al., 2010; Titus et al., 2002; 

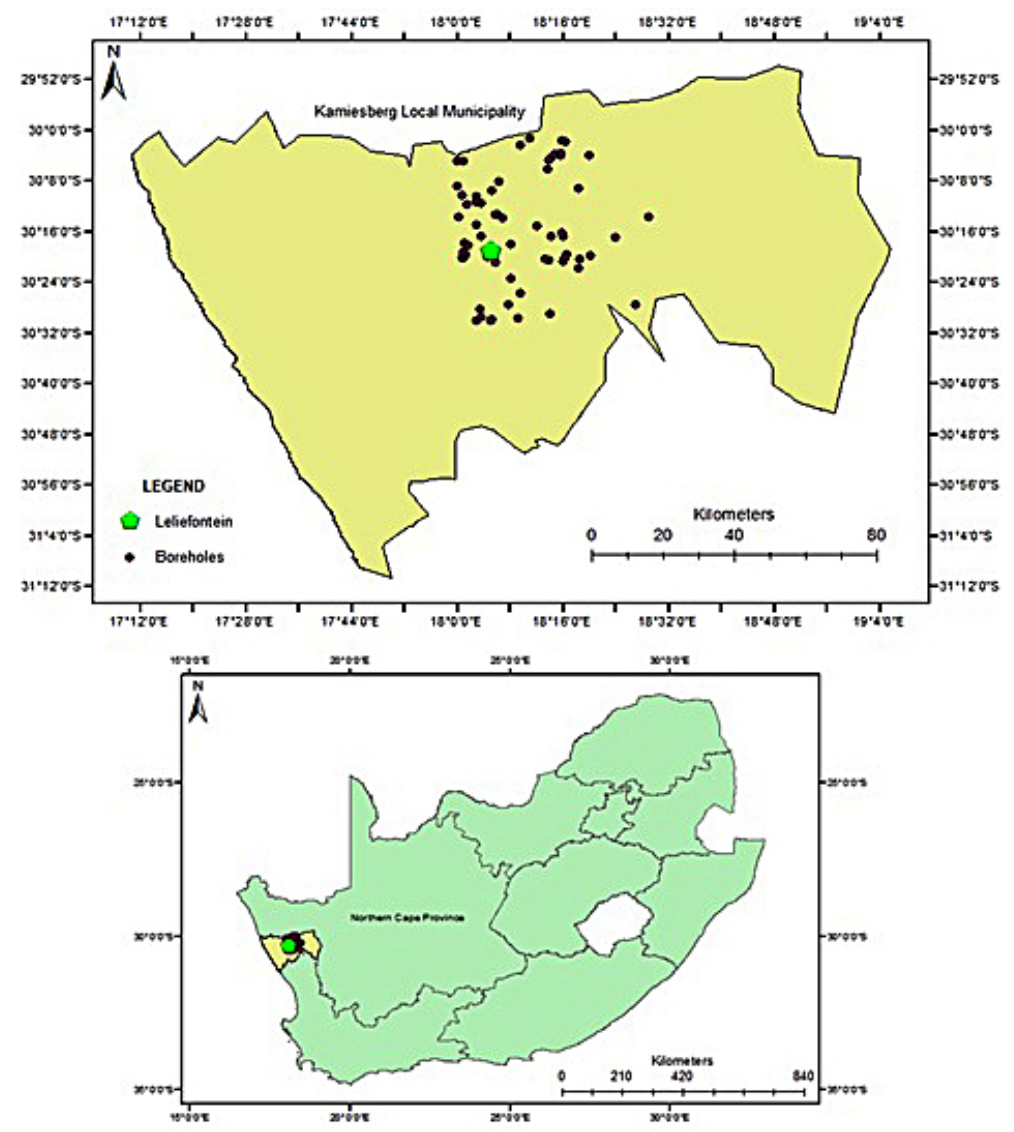

Figure 1. Map showing the location of Leliefontein and sampling boreholes

Leshomo, 2011). The distribution of boreholes and borehole identification numbers at the study location are shown on the map in Figure 2.

\section{Geology and hydrogeology of Kamiesberg}

A simplified geological map the study area presented in Figure 3. The geology of Kamiesberg consists of quaternary unconsolidated to cemented sand overlaying Kamieskroon leucocratic gneisses (Zirco, 2012). The relief of the area is flat to moderate with a general eastsoutheast slope toward the Atlantic Ocean. On the basis of the structural, lithological, and geochronological differences, Kamiesberg is located within the Namaqua Metamorphic Province, which is divided into four subprovinces (Kroner, 1976): the Kheis subprovince, the Namaqua

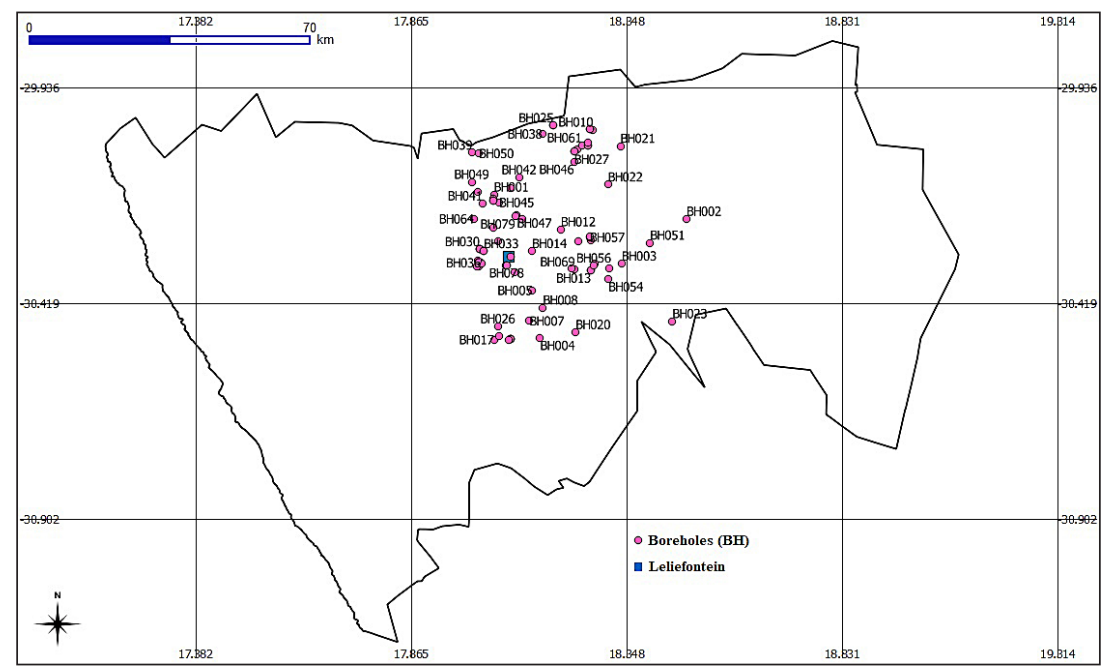

Figure 2. Map of borehole locations within the study catchment of Leliefontein 


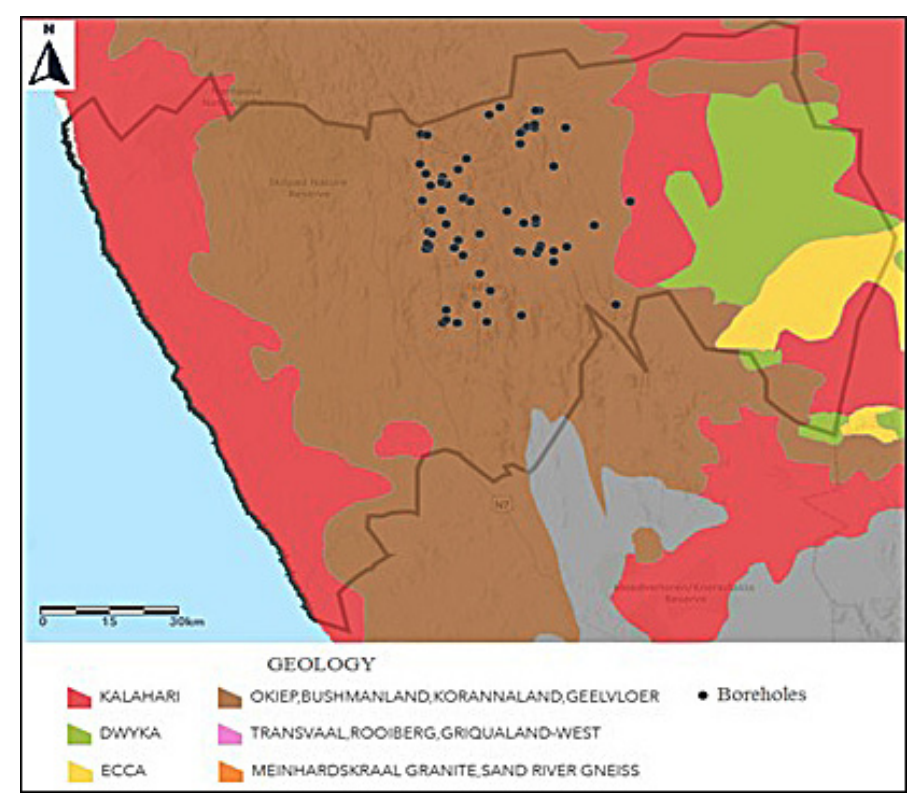

Figure 3. Geology of study location in the Northern Cape of South Africa

subprovince, the Richtersveld subprovince, and the Bushmanland subprovince. Leliefontein is located within the Bushmanland subprovince. Northern Cape, according to Slabbert et al., 1999 , is characterised by an intricate pattern of folding and faulting and complicated by a large number of granite intrusions.

Leliefontein is located in a region popularly called Namaqualand in the arid to the semi-arid western part of South Africa. The area is characterised by low rainfalls, which significantly impact the net recharge of its local aquifers. The groundwater in the Leliefontein exists in three aquifer systems, which are sandy alluvial aquifers, fractured bedrocks, and weathered zones. The fractured bedrocks and weathered zones form the basement aquifer systems in the region. The underlying geology of igneous and metamorphic rocks (granite and gneisses) influence the geometry of aquifer systems in the area (Pietersen et al., 2009). The recharge in the regions with no direct infiltration is presumably a result of regional flow from other neighbouring catchments.

The Leliefontein basement aquifers are made of fractured bedrocks and weathered regolith, with linear system structurally controlled by faults. The groundwater in the region is relatively saline, with high salt contents. The high salt concentration in groundwater is also attributed to the aquifer system lithology and the high evaporation rates of the region (Pietersen et al., 2009; Benito et al., 2010; Adams et al., 2010; Titus et al., 2002; Leshomo, 2011).

\section{Groundwater sample analysis}

The groundwater samples from 79 boreholes were collected and analysed for various water quality parameters. The accuracy of chemical analysis of groundwater samples is essential to the assessment and interpretation of hydrochemical data, and therefore, require the accuracy checks and verifications to ascertain the data quality integrity. The electroneutrality principle is an excellent method of water chemistry data verification. The electroneutrality principle states that the sum of positive and negative charges of the water must be balanced or be equal to zero. The acceptance criteria for the percentage difference is $<5 \%$, which is calculated with the equation:

:N. $[\%]=\left|\frac{\sum \text { Cations }[\mathrm{meq} / \mathrm{l}]+\sum \text { Anions }[\mathrm{meq} / \mathrm{l}]}{\sum \text { Cations }[\mathrm{meq} / \mathrm{l}]-\sum \text { Anions }[\mathrm{meq} / \mathrm{l}]} * 100 \%\right|<5 \%$

The calculations of electroneutrality (EN\%) for each sample, indicate that 76 out of the 79 samples have an electroneutrality lesser than $5 \%$, implying $96.2 \%$ of the samples were within the acceptable limit. The plausibility of a chemical analysis is a comparison of chemical values for process variables (cations and anions) for determination of the errors in measurements. It is determined by the calculated total cation, total anion and the EC of the water samples with the equation:

$$
\begin{aligned}
& \sum \text { Anions }[\mathrm{meq} / \mathrm{l}] \approx \sum \text { Cations }[\mathrm{meq} / \mathrm{l}] \approx \\
& \approx \frac{\mathrm{EC}[\mu \mathrm{S} / \mathrm{cm}]}{100} \pm 10 \% \text { for } \mathrm{EC}<2000 \mu \mathrm{S} / \mathrm{cm}
\end{aligned}
$$


Groundwater or water generally is electrically neutral, and therefore, calculating charge balance is useful for verifying the accuracy of chemical analysis (Cogho et al., 1989). For a given water sample, the sum in milliequivalents per litre (meq/l) of the positively-charged and negativelycharged species must be equal (Younger, 2007).

\section{Statistical analysis}

The choice of statistical methods involves the scientific process of a model building using both inductive and deductive reasoning. Selection of the right statistical method requires the knowledge of the characteristics of the data. The hydrochemical data was subjected to Pearson's correlation matrices, cluster analysis by agglomerative hierarchical clustering and principal component analysis for statistical interpretation, to determine the relationship between groundwater parameters and influencing factors (Usunoff \& Guzman-Guzman, 1989; Schot \& Van der Wal, 1992; Swan, 1995). Piper diagram and Chadha diagrams were also used for water type classification (Piper, 1944; Chadha; 1999).

\section{Water quality index}

The use of Water Quality Index (WQI) is a valuable method for classifying the levels of contamination for surface water and groundwater resources (Backman et al., 1998; StambukGiljanovic, 1999). The purpose is a classification based on a grading scale of 0 to 300 . The lower values on the grading scale are excellent while the increasing ones indicate increasing contamination levels. WQI calculation is derived from the following procedures:

1) Calculate the relative weight by using the equation:

$$
\mathrm{W}_{\mathrm{i}}=\frac{\mathrm{w}_{\mathrm{i}}}{\sum_{\mathrm{i}}^{\mathrm{n}} \mathrm{w}_{\mathrm{i}}}
$$

where: $W_{i}$ - relative weight of each parameter,

$w_{i}$ - weight of each parameter, and $\mathrm{n}$ is the total number of parameters.

2) Calculate $Q$ value using the equation:

$$
\mathrm{Q}_{\mathrm{i}}=\frac{\mathrm{C}_{\mathrm{i}} \times 100}{\mathrm{~S}_{\mathrm{i}}}
$$

where: $Q_{i}$ - quality rating,

$C_{i}$ - concentration of each parameter (mg/l),

$S_{i}$-SANS214(2015) water quality standard.
3) WQI is then calculated using the equation:

$$
\mathrm{WQI}=\sum \mathrm{W}_{\mathrm{i}} \times \mathrm{Q}_{\mathrm{i}}
$$

\section{Groundwater quality spatial distribution}

The geostatistical method of Inverse Distance Weighting (IDW), is useful for spatial analysis to predict the groundwater quality over and area to produce image maps (Shepard, 1968; Bartier \& Keller, 1996). The method also accurately checks the influence distances of all the points (Bartier \& Keller, 1996). The IDW spatial analysis in ArcGIS 10.8 was used to interpolate and predict the distribution of ions in groundwater at Leliefontein to generate a pollution map (ESRI, 2019). IDW is a mechanical spatial prediction model which is flexible, empirical, and constitutes a widely used mechanical spatial prediction model (Lam, 1983; Myers, 1995; Mitas \& Mitasova, 1999). Mechanical prediction models sometimes perform well or better compared to statistical models, and one such spatial prediction technique is the IDW (Shepard, 1968). For IDW interpolation, the value of the targeted parameters at a new point was derived as an average weight using the equation:

$$
\hat{\mathrm{z}}\left(\mathrm{s}_{0}\right)=\sum_{\mathrm{i}=1}^{\mathrm{n}} \lambda_{\mathrm{i}}\left(\mathrm{s}_{0}\right) * \mathrm{z}\left(\mathrm{s}_{\mathrm{i}}\right)
$$

where: $\lambda_{\mathrm{i}}$ - weight for neighbour $i$, and the sum of weights must to equal 1 to achieve unbiased interpolator. Equation, (6) is then changed to matrix form to the equation:

$$
\widehat{\mathrm{z}}\left(\mathrm{s}_{0}\right)=\lambda_{0}^{\mathrm{T}} * \mathrm{z}
$$

The inverse distance from known points to unknown points is used to determine the weights using the equation:

$$
\lambda_{\mathrm{i}}\left(\mathrm{s}_{0}\right)=\frac{\frac{1}{\mathrm{~d}^{\beta}\left(\mathrm{s}_{0}, \mathrm{~s}_{\mathrm{i}}\right)}}{\sum_{\mathrm{i}=0}^{\mathrm{n}} \frac{1}{\mathrm{~d}^{\beta}\left(\mathrm{s}_{0}, \mathrm{~s}_{1}\right)}} ; \beta>1
$$

where: $d\left(s_{o}, s_{i}\right)-$ distance from the new point to a known sampled point;

$\beta$ - coefficient used to adjust the weights. The IDW method is based on Waldo Tobler's first law which stipulates the relation of everything to one another, with near things relating more to each other than the distant ones (Tobler, 1970). 


\section{RESULTS AND DISCUSSION}

\section{Statistical analysis}

\section{Descriptive statistics}

The statistical overview of the hydrochemical data of Leliefontein is presented in Table 1. The major groundwater components with minimum, maximum, average, and South African National Standards (SANS241, 2015) are shown for the study location. The groundwater $\mathrm{pH}$ ranges from 5.97 to 8.7, and $\mathrm{EC}$ is between 19.3 to 920 $\mathrm{mg} / \mathrm{l}$ (mean: 217.28). The bicarbonate $\left(\mathrm{HCO}_{3}{ }^{-}\right)$ concentration ranges from 26.47 to $367.37 \mathrm{mg} / 1$ (mean: 155.75), while the mean $\mathrm{Cl}$ and $\mathrm{SO}_{4}$ levels are 574.81 and $131.73 \mathrm{mg} / \mathrm{l}$, respectively. The mean $\mathrm{Na}^{+}$and $\mathrm{K}^{+}$concentrations are 267.39 and $6.88 \mathrm{mg} / \mathrm{l}$, respectively. The calcium concentration varies from 5.70 to $441.90 \mathrm{mg} / \mathrm{l}$, higher than magnesium concentration which varies between 3.30 to $315.50 \mathrm{mg} / \mathrm{l}$. High fluoride concentration ( 0.14 to $10.18 \mathrm{mg} / \mathrm{l}$ with mean: 2.48 ) was observed, with $71 \%$ of the groundwater samples exceeding the SANS241 recommended limits. The $\mathrm{NO}_{3}$ concentration was between 0.09 and 695.26 $\mathrm{mg} / \mathrm{l}$, and $25 \%$ of the groundwater samples exceed the SANS241 recommended limits.

\section{Correlation matrix}

Pearson's correlation matrix was used to determine the relationships between the parameter of the hydrochemistry data (Swan, 1995), and the results presented in Table 2 for correlations $>0.4$. The groundwater samples with correlations $>0.7$ were classified as strongly correlated and those with correlations between 0.5 to 0.7 were classified as moderately correlated at $<0.05$ significant level. A strong correlation was observed for the major elements, $\mathrm{Ca}, \mathrm{Mg}, \mathrm{Na}, \mathrm{Cl}, \mathrm{SO}_{4}$, Dissolved Major Salts (DMS) and SAR, and EC with correlations $>0.7$, which indicates their contribution to the groundwater salinity. Moderate correlations between 0.5 to 0.7 were observed between $\mathrm{HCO}_{3}$ with $\mathrm{pH}$, which indicates a trend of ion concentration increasing along with $\mathrm{pH}$. The salinity of groundwater usually is a result of increasing ion concentration, recharge water evaporation, and geological formations. Positive correlations between $\mathrm{Ca}, \mathrm{Na}, \mathrm{Mg}, \mathrm{SO} 4$, and DMS are an indication of contributions by evaporative salts.

\section{Factor analysis}

The application of factor analysis is a useful method for the interpretation of geohydrological data (Schot \& Van der Wal, 1992; Usunoff \& Guzman-Guzman, 1989; Ashley, 1978; Dawdy \& Feth, 1967). Factor analysis rearranges the data and presents it in a form that clearly explains the composition of the rudimentary system that produced the data (Dawdy \& Feth, 1967). The hydrochemical parameters were created into a set of factors, using varimax rotation factor analysis to determine the main factors responsible for the groundwater chemistry in Leliefontein. Five

Table 1. A statistical overview of groundwater hydrochemical data (values in $\mathrm{mg} / \mathrm{l}$ )

\begin{tabular}{|c|c|c|c|c|c|c|}
\hline \multicolumn{7}{|c|}{ Groundwater $(\mathrm{n}=79)$} \\
\hline Parameter & Mean & Median & Min & Max & Std Dev. & $\begin{array}{c}\text { Acceptable limits } \\
\text { (SANS241:2015) }\end{array}$ \\
\hline $\mathrm{EC}(\mathrm{mS} / \mathrm{m})$ & 217.28 & 165.60 & 19.30 & 920 & 202.26 & 170 \\
\hline $\mathrm{pH}$ & 7.50 & 7.52 & 5.97 & 8.70 & 0.55 & $\geq 5.0-\leq 9.7$ \\
\hline $\mathrm{Ca}^{2+}$ & 90.35 & 66 & 5.70 & 441.90 & 77.99 & $\leq 150$ \\
\hline $\mathrm{Mg}^{2+}$ & 67.17 & 43.60 & 3.30 & 315.50 & 68.87 & $\leq 70$ \\
\hline $\mathrm{Na}^{+}$ & 267.39 & 157.40 & 18 & 1568.50 & 323.13 & $\leq 200$ \\
\hline $\mathrm{K}^{+}$ & 6.88 & 3.30 & 0.56 & 111.31 & 13.94 & $\leq 50$ \\
\hline $\mathrm{Cl}^{-}$ & 574.81 & 374.06 & 28.71 & 3022.70 & 675.01 & $\leq 300$ \\
\hline $\mathrm{SO}_{4}{ }^{2-}$ & 131.73 & 92.80 & 4.50 & 563.90 & 128.08 & $\leq 250$ \\
\hline $\mathrm{F}$ & 2.48 & 2.37 & 0.14 & 10.18 & 1.65 & $\leq 1.5$ \\
\hline $\mathrm{Si}$ & 14.68 & 14.58 & 3.15 & 36.14 & 5.22 & - \\
\hline $\mathrm{PO}_{4}-\mathrm{P}$ & 0.02 & 0.01 & 0.003 & 0.49 & 0.06 & - \\
\hline $\mathrm{HCO}_{3}$ & 155.75 & 149.94 & 26.47 & 367.37 & 82.03 & - \\
\hline $\mathrm{NO}_{3}$ & 23.77 & 2.04 & 0.09 & 695.26 & 87.68 & $\leq 11$ \\
\hline $\mathrm{NO}_{4}-\mathrm{N}$ & 0.09 & 0.05 & 0.02 & 1.66 & 0.19 & $\leq 1.5$ \\
\hline $\mathrm{DMS}^{\mathrm{SAR}}$ & 1321.41 & 967.98 & 99 & 5892 & 1289.62 & - \\
\hline
\end{tabular}


Table 2. Pearson's correlation matrices for groundwater hydrochemical data (values in $\mathrm{mg} / \mathrm{l}$ )

\begin{tabular}{|c|c|c|c|c|c|c|c|c|c|c|c|c|c|c|c|c|}
\hline Parameter & $\mathrm{EC}$ & $\mathrm{pH}$ & $\mathrm{Ca}^{2+}$ & $\mathrm{Mg}^{2+}$ & $\mathrm{Na}^{+}$ & $\mathrm{K}^{+}$ & $\mathrm{Cl}^{-}$ & $\mathrm{SO}_{4}^{2-}$ & $\mathrm{F}$ & $\mathrm{Si}$ & $\mathrm{PO}_{4}$ & $\mathrm{HCO}_{3}$ & $\mathrm{NO}_{3}$ & $\mathrm{NO}_{4}$ & $\mathrm{DMS}$ & $\mathrm{SAR}^{2}$ \\
\hline $\mathrm{EC}$ & 1 & & & & & & & & & & & & & & & \\
\hline $\mathrm{pH}$ & & 1 & & & & & & & & & & & & & \\
\hline $\mathrm{Ca}^{2+}$ & 0.78 & & 1 & & & & & & & & & & & & \\
\hline $\mathrm{Mg}^{2+}$ & 0.95 & & 0.85 & 1 & & & & & & & & & & & & \\
\hline $\mathrm{Na}^{+}$ & 0.96 & & 0.60 & 0.84 & 1 & & & & & & & & & & & \\
\hline $\mathrm{K}^{+}$ & 0.62 & & & 0.48 & 0.68 & 1 & & & & & & & & & & \\
\hline $\mathrm{Cl}^{-}$ & 0.99 & & 0.77 & 0.95 & 0.96 & 0.62 & 1 & & & & & & & & & \\
\hline $\mathrm{SO}_{4}^{2-}$ & 0.96 & & 0.82 & 0.89 & 0.91 & 0.57 & 0.94 & 1 & & & & & & & & \\
\hline $\mathrm{F}$ & & 0.46 & & & & & & & 1 & & & & & & & \\
\hline $\mathrm{Si}$ & & & & & & & & & 0.04 & 1 & & & & & & \\
\hline $\mathrm{PO}_{4}-\mathrm{P}$ & & & & & & & & & 0.05 & & 1 & & & & & \\
\hline $\mathrm{HCO}_{3}$ & & 0.55 & & & 0.43 & & & & 0.41 & & & 1 & & & & \\
\hline $\mathrm{NO}_{3}$ & & & & & & & & & & & & & 1 & & \\
\hline $\mathrm{NO}_{4}-\mathrm{N}$ & & & & & & & & & & & & & & 1 & & \\
\hline $\mathrm{DMS}^{2}$ & 1.00 & & 0.79 & 0.94 & & 0.62 & 0.99 & 0.96 & & & & 0.40 & & & 1 & \\
\hline $\mathrm{SAR}^{0}$ & 0.79 & & & 0.58 & & 0.63 & 0.77 & 0.76 & 0.41 & & & 0.50 & & & 0.79 & 1 \\
\hline
\end{tabular}

factors were found to be responsible for $83.12 \%$ of the variance in the data set, as shown in Table 3. Factor 1 indicated a strong relationship contributing to the groundwater salinity at Leliefontein. The main contributing parameters to the salinity of groundwater are $\mathrm{EC}, \mathrm{Ca}, \mathrm{Mg}, \mathrm{Na}, \mathrm{K}, \mathrm{Cl}, \mathrm{SO}_{4}$, $\mathrm{HCO}_{3}, \mathrm{DMS}$ and SAR. The principal cations $\mathrm{Na}$, $\mathrm{Ca}, \mathrm{Mg}$, and $\mathrm{K}$ correlated positively indicating the influence of the geological formations. The positive correlations between $\mathrm{Ca}, \mathrm{Mg}$ and $\mathrm{SO}_{4}$ are an indication of possible dissolution or precipitation of sulphide minerals. Factor 2 shows the positive effect of $\mathrm{pH}$ on $\mathrm{F}, \mathrm{HCO}_{3}$ and $\mathrm{SAR}$, and the negative correlation of $\mathrm{NO}_{3}$ (unknown relationship). The factor 2 parameters are the determinants of the mobility and solubility of the trace elements such as fluoride found in the groundwater samples. Factor 3 gives the correlation of $\mathrm{NO}_{4}-\mathrm{N}$ of the groundwater, while Factor 4 and Factor 5 relate the correlation of $\mathrm{NO}_{3}$ and $\mathrm{PO}_{4}-\mathrm{P}$ respectively for the groundwater samples, an indication of the anthropogenic processes.

\section{Agglomorate hierarchical clustering (AHC)}

The application of cluster analysis results in the identification of different chemical facies

Table 3. Factor analysis of groundwater hydrochemical data (values in mg/l)

\begin{tabular}{|c|c|c|c|c|c|}
\hline Parameter & Factor 1 & Factor 2 & Factor 3 & Factor 4 & Factor 5 \\
\hline EC & 0.992 & & & & \\
\hline $\mathrm{pH}$ & & 0.737 & & & \\
\hline $\mathrm{Ca}^{2+}$ & 0.771 & & & & \\
\hline $\mathrm{Mg}^{2+}$ & 0.921 & & & & \\
\hline $\mathrm{Na}^{+}$ & 0.963 & & & & \\
\hline $\mathrm{K}^{+}$ & 0.657 & & & & \\
\hline $\mathrm{Cl}^{-}$ & 0.981 & & & & \\
\hline $\mathrm{SO}_{4}^{2-}$ & 0.965 & & & & \\
\hline $\mathrm{F}$ & & 0.674 & & & -0.495 \\
\hline $\mathrm{Si}$ & & & -0.593 & & \\
\hline $\mathrm{PO}_{4}-\mathrm{P}$ & & 0.419 & & 0.492 & 0.656 \\
\hline $\mathrm{HCO}_{3}$ & 0.446 & 0.704 & & & \\
\hline $\mathrm{NO}_{3}$ & & -0.452 & -0.490 & 0.582 & \\
\hline $\mathrm{NO}_{4}-\mathrm{N}$ & & & 0.612 & & \\
\hline DMS & 0.993 & & & & \\
\hline SAR & 0.822 & 0.403 & & & \\
\hline Explained Variance & 7.691 & 2.204 & 1.377 & 1.081 & 0.946 \\
\hline Cum. $\%$ of Variance & 48.065 & 61.843 & 70.449 & 77.208 & 83.119 \\
\hline
\end{tabular}


of the groundwater by means of the Q-mode AHC method. From the AHC analysis, the result shows that the determining factor the grouping of the groundwater hydrochemistry data into three groups are the sodium and chloride ion concentrations, an indication of the salinity associated with the groundwater samples (Figure 4). In Group 1 there are 57 groundwater samples from boreholes (BH001, BH002, BH004, BH006 - BH011, BH014 - BH019, BH022, BH023, ВH026, ВH029 - BH035, ВH037 BH043, BH045 - BH047, BH049 - BH050, BH053, BH056 - BH058, BH061 - BH067, BH069, BH071 - BH076, BH078, and BH079). These 57 wells have a mean concentration of $269.88 \mathrm{mg} / \mathrm{l}$ for $\mathrm{Cl}, 146.02 \mathrm{mg} / 1$ for $\mathrm{HCO}_{3}$, and $129 \mathrm{mg} / \mathrm{l}$ for $\mathrm{Na}$, representing the lowest salinity water group of the three groups. The order of concentration of the major ions in Group 1 water samples is as follows $\mathrm{Na}^{+}>\mathrm{Ca}^{2+}>\mathrm{Mg}^{2+}>\mathrm{K}^{+}$ and $\mathrm{Cl}^{-}>\mathrm{HCO}_{3}>\mathrm{SO}_{4}>\mathrm{NO}^{3}$. The hydrochemical water type is characterized by sodium chloride with $\mathrm{Na}(\min =18 \mathrm{mg} / 1, \max =225.5 \mathrm{mg} / 1$, and mean $=129 \mathrm{mg} / \mathrm{l})$, and sodium $(\mathrm{min}=28.71$ $\mathrm{mg} / \mathrm{l}, \max =586.1 \mathrm{mg} / \mathrm{l}$, and mean $=269.88$ $\mathrm{mg} / \mathrm{l}) . \mathrm{HCO}_{3}$ also exist $(\mathrm{min}=26.47 \mathrm{mg} / \mathrm{l}$, $\max$ $=341.53 \mathrm{mg} / \mathrm{l}$, and mean $=146.02 \mathrm{mg} / \mathrm{l}$ ) with calcium. $19.3 \%$ of Group 1 boreholes samples exceeded the recommended $\mathrm{Na}$ limit in drinking water, and $35.1 \%$ of boreholes exceeded the $\mathrm{Cl}$ concentration stipulated by SANS241:2015.

Group 2 is comprised of 19 boreholes (BH003, BH005, BH012, BH013, BH020, BH021, BH024, BH025, BH027, BH028, BH036, ВH044, BH048,
BH051, BH052, BH054, BH055, BH059, and BH068) with a mean concentration of 1487.85 $\mathrm{mg} / \mathrm{l}$ for $\mathrm{Cl}, 648.07 \mathrm{mg} / \mathrm{l}$ for $\mathrm{Na}$, and $306.46 \mathrm{mg} / \mathrm{l}$ for $\mathrm{SO}_{4}$. The order of concentration of the major ions is $\mathrm{Na}^{+}>\mathrm{Ca}^{2+}>\mathrm{Mg}^{2+}>\mathrm{K}^{+}$, and $\mathrm{Cl}^{-}>\mathrm{SO}_{4}>$ $\mathrm{HCO}_{3}>\mathrm{NO}_{3}$, and the hydrochemical characteristics are the same as in Group 1. The hydrochemical water type is sodium chloride with $\mathrm{Na}$ ( $\mathrm{min}$ $=234.67 \mathrm{mg} / 1$, $\max =1568.5 \mathrm{mg} / 1$, and mean $=$ $648.07 \mathrm{mg} / \mathrm{l})$, and chloride $(\mathrm{min}=567.91 \mathrm{mg} / 1$, $\max =3022.7 \mathrm{mg} / \mathrm{l}$, and mean $=1487.85 \mathrm{mg} / \mathrm{l})$. $\mathrm{SO}_{4}$ also exist $(\min =135.9 \mathrm{mg} / \mathrm{l}, \max =563.9$ $\mathrm{mg} / \mathrm{l}$, and mean $=306.46 \mathrm{mg} / \mathrm{l}$ ) with calcium. All the boreholes in the group 2 water samples exceeded the recommended $\mathrm{Na}$ and $\mathrm{Cl}$ limit for drinking water, and $52.6 \%$ of the boreholes have the water samples with $\mathrm{SO}_{4}$ above the limit guideline recommended by SANS241:2015. The $\mathrm{SO}_{4}$ concentration is a likely contributing factor for the average lowest $\mathrm{pH}$ in Group 2.

Group 3 is made up of three boreholes (BH060, BH070, and BH077) with a mean concentration of $485.86 \mathrm{mg} / \mathrm{l}$ for $\mathrm{Na}, 585.95 \mathrm{mg} / \mathrm{l}$ for $\mathrm{Cl}$, and $277.59 \mathrm{mg} / 1$ for $\mathrm{HCO}_{3}$. The order of concentration of the major ions is $\mathrm{Na}^{+}>\mathrm{Ca}^{2+}>$ $\mathrm{Mg}^{2+}>\mathrm{K}^{+}$and $\mathrm{Cl}^{-}>\mathrm{HCO}_{3}>\mathrm{SO}_{4}>\mathrm{NO}_{3}$. The water type is also sodium chloride with $\mathrm{Na}$ ( $\mathrm{min}=$ $466.77 \mathrm{mg} / \mathrm{l}$, $\max =508.02 \mathrm{mg} / \mathrm{l}$, mean $=485.86$ $\mathrm{mg} / \mathrm{l}), \mathrm{Cl}(\min =495.86 \mathrm{mg} / \mathrm{l}, \max =677.3$ $\mathrm{mg} / \mathrm{l}$, and mean $=585.95 \mathrm{mg} / \mathrm{l})$, and $\mathrm{HCO}_{3}(\mathrm{~min}$ $=166.04 \mathrm{mg} / \mathrm{l}, \max =367.37 \mathrm{mg} / \mathrm{l}$, and mean $=277.59 \mathrm{mg} / \mathrm{l})$. All the boreholes in Group 3 exceeded $\mathrm{Na}$ and $\mathrm{Cl}$ SANS241:2015 guideline limit for drinking water.

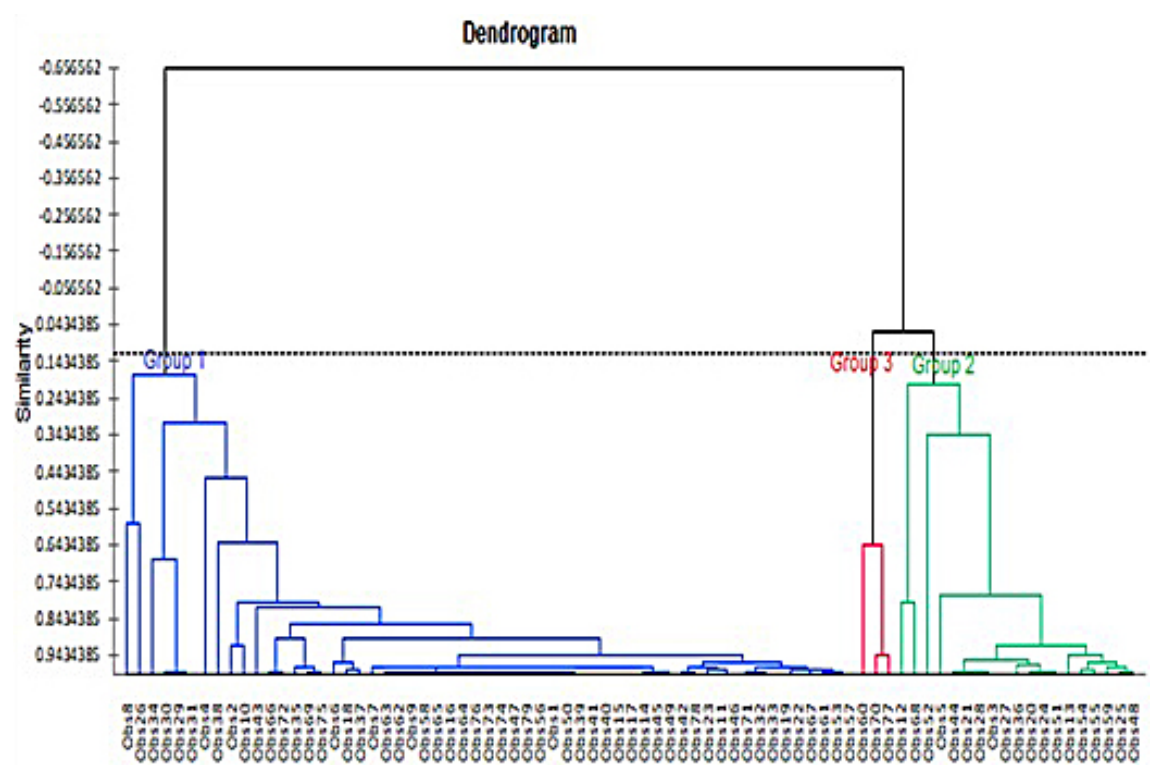

Figure 4. Dendrogram of Q mode cluster analysis of water simples 


\section{Groundwater types}

The Piper and Chadha diagrams for the chemistry of Leliefontein hydrochemical data are presented in Figure 5. The water types in piper plots are generally classified into six groups, which are $\mathrm{Ca}-\mathrm{HCO}_{3}$ type, $\mathrm{Na}-\mathrm{Cl}$ type, $\mathrm{Ca}-\mathrm{Mg}-\mathrm{Cl}$ type, Ca$\mathrm{Na}-\mathrm{HCO}_{3}$ type, $\mathrm{Ca}-\mathrm{Cl}$ type, and $\mathrm{Na}-\mathrm{HCO}_{3}$ type. The piper plot by WISH shows the water types falling into three groups of $\mathrm{Na}-\mathrm{Cl}$ type, $\mathrm{Ca}-\mathrm{Cl}$ type, and $\mathrm{Na}-\mathrm{HCO}_{3}$ type. Group 1 has $\mathrm{Na}-\mathrm{Cl}, \mathrm{Ca}-\mathrm{Cl}$ and $\mathrm{Na}-\mathrm{HCO}_{3}$ water types, Group 2 water was classified as $\mathrm{Na}-\mathrm{Cl}$ and $\mathrm{Ca}-\mathrm{Cl}$ water type, and Group 3 is $\mathrm{Na}-\mathrm{Cl}$ water type. The Chadha diagram is a modified version of the Piper diagram, is useful for the verification of water type classification. The Chadha plots show that $\mathrm{Na}$ and $\mathrm{Cl}$ characterised most of the groundwater at Leliefontein. Most of the boreholes indicated seawater $\mathrm{Na}-\mathrm{Cl}$ water type and reverse ion-exchange $\mathrm{Ca}-\mathrm{Mg}-\mathrm{Cl} / \mathrm{SO}_{4}$ water type. Only two of the boreholes showed base ion-exchange $\mathrm{Na}-\mathrm{HCO}_{3}$ water type. The Chadha diagram affirms the classification by Piper plot groundwater type analysis.

\section{Hydrogeochemical processes}

The scatter plots of dissolved major salts (DMS) versus the major cations $\left(\mathrm{Na}^{+}, \mathrm{Ca}^{2+}\right.$, $\left.\mathrm{Mg}^{2+}\right)$, and DMS versus major anions $\left(\mathrm{Cl}^{-}, \mathrm{HCO}_{3}^{-}\right.$ , $\mathrm{SO}_{4}^{2-}$ ) are presented in Figure 6. A consistent relationship between DMS and cations/anions was observed. All ion concentrations increased along with the concentration of DMS,. The major cations concentration increases in the sequence of $\mathrm{Na}^{+}>\mathrm{Ca}^{2+}>\mathrm{Mg}^{2+}$, and major anions concentration also increases in the sequence of $\mathrm{Cl}^{-}>\mathrm{HCO}_{3}^{-}$ $>\mathrm{SO}_{4}{ }^{2-}$. The possible explanation of the trend

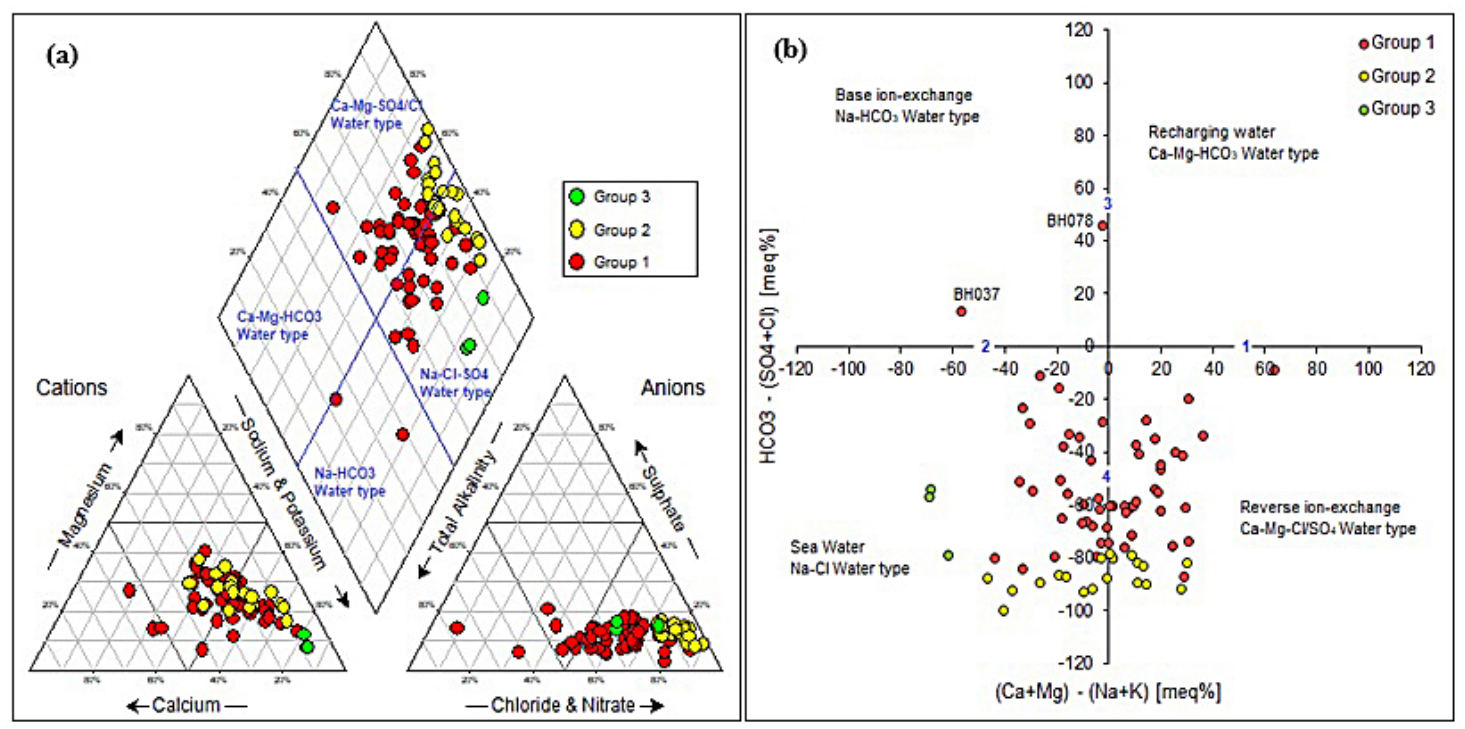

Figure 5. (a) Piper diagram (b) Chadha diagram for the chemistry of water at Leliefontein

(a)

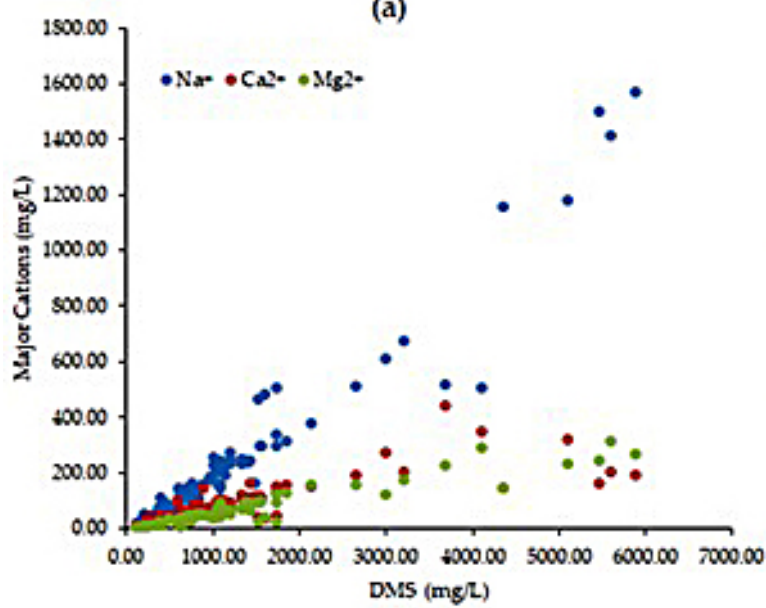

(b)

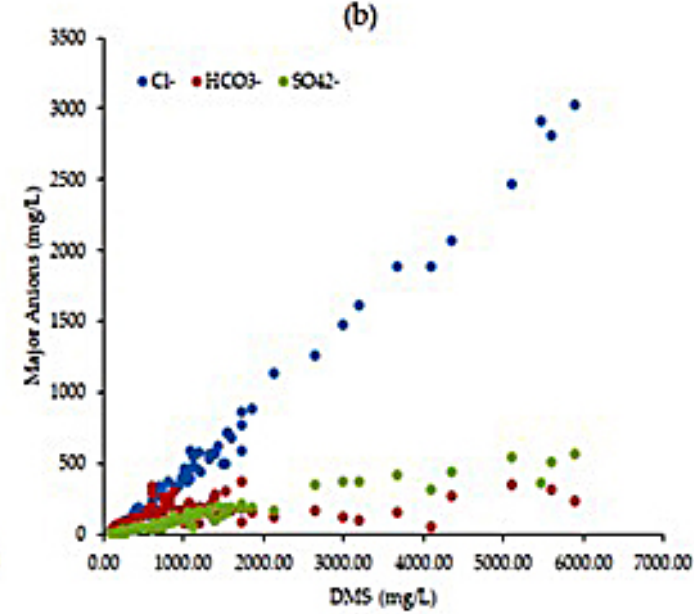

Figure 6. Scatter plots of (a) main cations vrs. DMS, (b) main anions vrs. DMS 
between DMS and the major ions, is the dissolution of the minerals containing $\mathrm{Na}^{+}$and $\mathrm{Cl}^{-}$was responsible for major hydrochemical processes in the groundwater.

\section{The weathering of silicates}

The weathering of silicate is one crucial geological process that dominates the chemical interaction of major ions in groundwater (Mackenzie $\&$ Garrells, 1965). The ratio of $\mathrm{Na}: \mathrm{Cl}$, when approximately equal to one is an indication of halite dissolution and responsible for sodium concentrations, and when the proportion is higher than one it is interpreted as silicate weathering leading to the release of sodium (Mayback, 1987; Li et al., 2016). The water samples from the boreholes in Leliefontein as seen on the scatter plot in Figure 7(a) shows the ions cluster above the $\mathrm{Na}: \mathrm{Cl} 1: 1$ line, an indication of sodium release as a result of silicate weathering. Studies have shown that the weathering of silicate as a sodium source produces $\mathrm{HCO}_{3}^{-}$as the predominant anion (Rogers, 1987; Rajmohan \& Elango, 2004). In this study, $\mathrm{HCO}_{3}^{-}$is not the dominant anion; it is chloride which is the dominant anion, as seen in Figure 7(b).

The weathering of silicate can further be probed by estimating the $\mathrm{Na}^{+}$to total cation $\left(\mathrm{TC}^{+}\right)$ ratio in groundwater. In this study, the groundwater samples are reclining about $0.57 \mathrm{CT}^{+}$below $1: 1 \mathrm{Na}^{+}: \mathrm{CT}^{+}$line, an indication of limited silicate weathering (Figure $7 \mathrm{~b}$ ). The plot of $\mathrm{TA}^{-}: \mathrm{Cl}^{-}$reclining below the equiline (Figure $7 \mathrm{c}$ ) indicates the abundance or formation of chlorides in the limited silicate weathering process. The scatter plot of $\mathrm{Ca}^{2+}+\mathrm{Mg}^{2+}$ against $\mathrm{SO}_{4}{ }^{2-}+\mathrm{HCO}_{3}-$ presented in Figure 7(d) clusters most groundwater samples below the equiline at the $\mathrm{SO}^{2-}+\mathrm{HCO}^{3-}$ side of the $\mathrm{Ca}^{2+}+\mathrm{Mg}^{2+}: \mathrm{SO}_{4}^{2-}+\mathrm{HCO}_{3-} 1: 1$ ratio, an indication of carbonate weathering and sulfuric acidity during hydrogeochemical processes. The scatter plot of $\mathrm{Ca}^{2+}+\mathrm{Mg}^{2+}$ against $\mathrm{SO}_{4}^{2-}+\mathrm{HCO}_{3}^{-}$showing
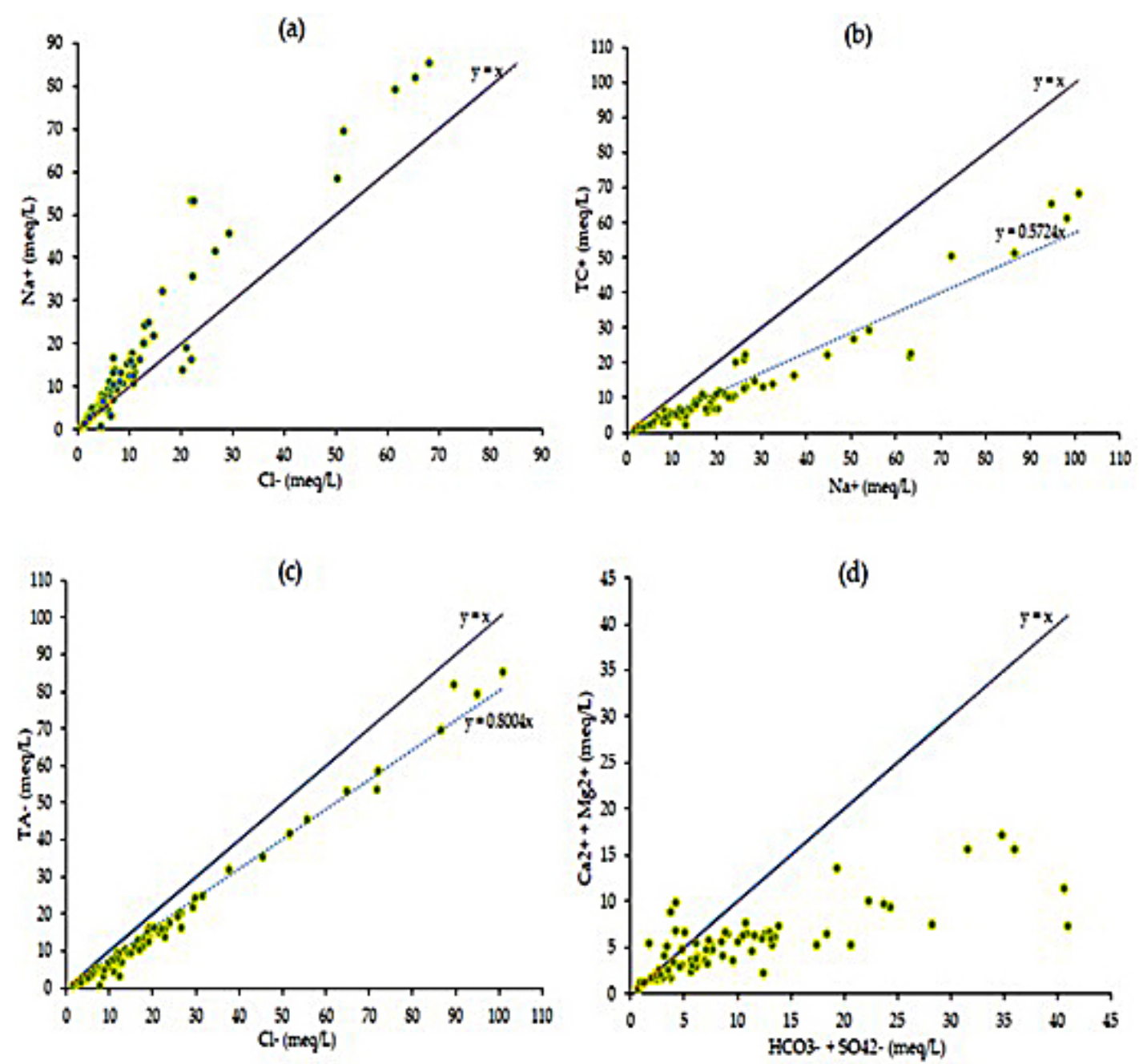

Figure 7. Scatter plots of (a) $\mathrm{Na}^{+} \mathrm{vrs} \mathrm{Cl}^{-}$, (b) $\mathrm{Na}^{+}$vrs $\mathrm{TC}^{+}$, (c) $\mathrm{Cl}^{-} \mathrm{vrs} \mathrm{TA}^{-}$, and (d) $\left(\mathrm{HCO}_{3}^{-}+\mathrm{SO}_{4}^{2-}\right)$ vrs $\left(\mathrm{Ca}^{2+}+\mathrm{Mg}^{2+}\right)$ 
the groundwater samples clustering almost along the equipotential line, is an indication of possible carbonate and silicate origination of ions (Datta \& Tyagi, 1996; Fisher \& Mullican, 1997).

\section{Carbonate weathering and dissolution}

Studies have shown that when the ratio $\mathrm{Ca}^{2+} /$ $\mathrm{Mg}^{2+}$ is equal to 1 , the dissolution of dolomite is highly likely and the ratio greater than 1 (ratio $>1$ ), constitutes an indication of the calcite dissolution (Maya \& Loucks, 1995). The scatter plot of $\mathrm{Ca}^{2+}$ against $\mathrm{Mg}^{2+}$ for the groundwater samples shows that the dissolution of dolomite dominates calcite dissolution (Figure 8e). Most groundwater samples $(80 \%)$ are distributed near the $\mathrm{Ca}^{2+}$ $\mathrm{Mg}^{2+}$ equiline, which means a predominant dolomite dissolution. About $20 \%$ of the groundwater samples have ratio $>1$, an indication of calcite dissolution in hydrogeochemical process; $11 \%$ of the groundwater from Leliefontein recline below the equiline of $\mathrm{Mg}^{2+}$ versus $\mathrm{Ca}^{2+}$ scatter plot, indicating less calcite dissolution. There is clustering at the $\mathrm{Ca}^{2+}+\mathrm{HCO}_{3}$ side of the 1:1 $\mathrm{Ca}^{2+}+\mathrm{HCO}_{3}: \mathrm{Na}^{+}+\mathrm{Cl}^{-}$equiline, an indication of calcium and bicarbonate solubility and formation of sodium chloride (Figure $8 \mathrm{f}$ ). The solubility of calcium is limited compared to carbonate, and most of the calcium precipitates as calcium carbonated (Data \& Tyagi, 1996).

\section{General hydrochemistry}

The EC of groundwater at Leliefontein varies and the recommended limit for drinking water by SANS241:2015 guideline of $170 \mathrm{mS} / \mathrm{m}$ at $300{ }^{\circ} \mathrm{C}$. In this study, the EC ranges from 19.3 to $920 \mathrm{mS} / \mathrm{cm}$ at the study location. Out of the 79 boreholes sampled in the study area, 40 boreholes $(50.6 \%)$ are within the guideline limit, and 39 boreholes (49.4\%) are above the recommended guideline limit of SANS241:2015. The high electrical conductivity in some boreholes may be as a result of the high evapotranspiration rate contributing to the high salinity. High EC may be as a result of hydrogeological conditions and not necessarily an indication of the presence of pollution. The $\mathrm{pH}$ is one of the critical water quality parameters and in the study area it varies between 5.97 to 8.7 . The drinking water quality guideline recommended a $\mathrm{pH}$ of 7.0 to 8.5 for freshwater (SANS241, 2015). The $\mathrm{pH}$ measurements at the study area, $81 \%$ of the boreholes sampled have the $\mathrm{pH}$ values within an acceptable range and $19 \%$ out of the recommended range values of SANS241.

Naturally, chloride is present in all water at various concentrations influenced by geochemical processes. Major salts like sodium chloride, potassium chloride, calcium chloride and magnesium chloride are highly soluble in water. Chloride in groundwater predominantly originates from igneous and metamorphic rocks such as granite-gneiss. Chloride can also accumulate in groundwater as a result of irrigation return flows, seawater intrusion, and other anthropogenic activities. Chloride in domestic water produces a salty taste of water and escalates the corrosion rate of metals. The SANS241:2015 guidelines for the $\mathrm{Cl}$ concentration in drinking water are $\leq 300$ $\mathrm{mg} / \mathrm{l}$. Out of the 79 boreholes, 34 boreholes (43\%) have the $\mathrm{Cl}$ concentrations within the guideline limit value, and 45 boreholes (57\%) of have chloride concentration exceeding $300 \mathrm{mg} / \mathrm{l}$ acceptable limit value of SANS241.
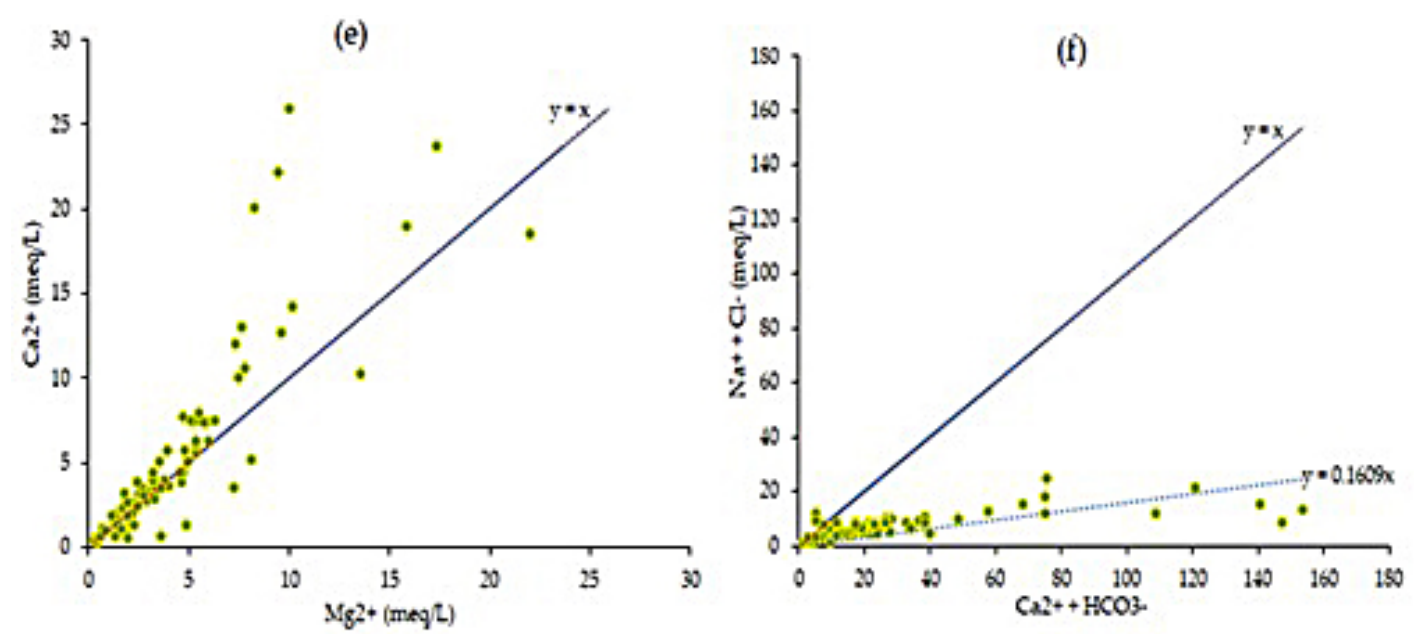

Figure 8. Scatter plots of (e) $\mathrm{Ca}^{2+}$ vrs. $\mathrm{Mg}^{2+}$ and (f) $\mathrm{Na}^{+}+\mathrm{Cl}^{-}$vrs. $\mathrm{Ca}^{2+}+\mathrm{HCO}_{3}$ 
Sodium is a highly soluble natural chemical element and found in groundwater. An increase in the sodium concentration in groundwater above natural levels is an indicate pollution from a point or non-point. The SANS241 guideline value for sodium concentration is $<200 \mathrm{mg} / \mathrm{l}$. Out of the 79 boreholes, 36 boreholes (45.6\%) have the sodium concentration $>200 \mathrm{mg} / \mathrm{l}$, and 43 boreholes (54.4\%) are within acceptable limit of $<200 \mathrm{mg} / 1$ for the study location.

Fluoride minerals mostly occur as fluor-spar, calcium fluoro-phosphate, and fluor-apatite, and associated with volcanic rocks. Hydrogen fluoride is a soluble gas in magmas emanating from volcanic eruptive activities. Phosphate fertilisers also contribute significantly to the fluoride content in soil and groundwater resources. The weathering of micaceous rock such as granite and gneisses also produces fluoride in groundwater, prevails as a result of rock-water interaction, long residence time and evapotranspiration. The SANS241 guidelines set out for drinking water for fluoride concentration is $\leq 1.5 \mathrm{mg} / \mathrm{l}$ (DWAF, 1996). The study shows that $72 \%$ of the boreholes in Leliefontein have the fluoride concentration above an acceptable range $>1.5 \mathrm{mg} / \mathrm{l}$, while the remaining $28 \%$ are within an acceptable range of $\leq 1.5 \mathrm{mg} / \mathrm{l}$. The high fluoride concentrations in the groundwater of Leliefontein are a significant problem to the quality of groundwater in the region. High levels of fluoride in drinking water are the cause of skeletal fluorosis with crippling, as well as the loss of teeth.

The nitrate and nitrite ions form part of the nitrogen cycle and occur naturally in many ecosystems, with nitrate ion $\left(\mathrm{NO}_{3}\right)$ is the stable form. The recommended DWAF guideline set out for drinking waters nitrate concentration not exceeding $\leq$ $11 \mathrm{mg} / \mathrm{l}-\mathrm{N}$, and high levels have adverse health effects on infants of less than two years old (DWAF, 1996). In Leliefontein, $74.7 \%$ of the boreholes show the nitrate concentrations lesser than $11 \mathrm{mg} / 1$ and are within the acceptable range, while $25.3 \%$ were above the guideline acceptable limit.

\section{Sodium adsorption ratio and EC}

The related concentration of $\mathrm{Na}, \mathrm{Ca}$, and $\mathrm{Mg}$ is an essential indicative factor of the suitability of water for agricultural (irrigation application). elevated $\mathrm{Na}$ and low $\mathrm{Ca}$ and $\mathrm{Mg}$ in the water for irrigation results in cation exchange complex becoming saturated with $\mathrm{Na}$. The high $\mathrm{Na}$ concentration leads to soil structure deformation as a result of the dispersion of clay particles, decreased permeability and aeration, which affects the plant growth. SAR is used to assess the risk of $\mathrm{Na}$ anomalies in groundwater (Fetter, 1994):

$$
\mathrm{SAR}=\frac{\mathrm{Na}}{\sqrt{\mathrm{Ca}+\mathrm{Mg}} / 2}
$$

The SAR measurements of the groundwater samples for Leliefontein with the hazard classification is presented in the SAR diagram using WISH (Lukas, 2012) in Figure 9.

The sodium hazard is also useful for the determination of water use of water for irrigation. According to Fipps (2003), there are two types of problems associated with salt in water for irrigation, salt associated with the total salinity (EC) and salt associated with sodium (SAR); or a combination of both. The classification of groundwater at the study site for irrigation purpose based on SAR is presented in Table 4. From the rating, all group 1 water samples have a low SAR, group 2 ranges from a low SAR to medium and high SAR, while all the group 3 water samples indicated high SAR. Therefore, according to Fipps (2003) and Aza-Gnandji et al., 2013, the water with low sodium hazard is suitable for irrigation. Generally, 91.1\% of boreholes in Leliefontein are ideal for the irrigation purposes based on SAR values. The classification of groundwater from the boreholes at Leliefontein for the irrigation purposes based

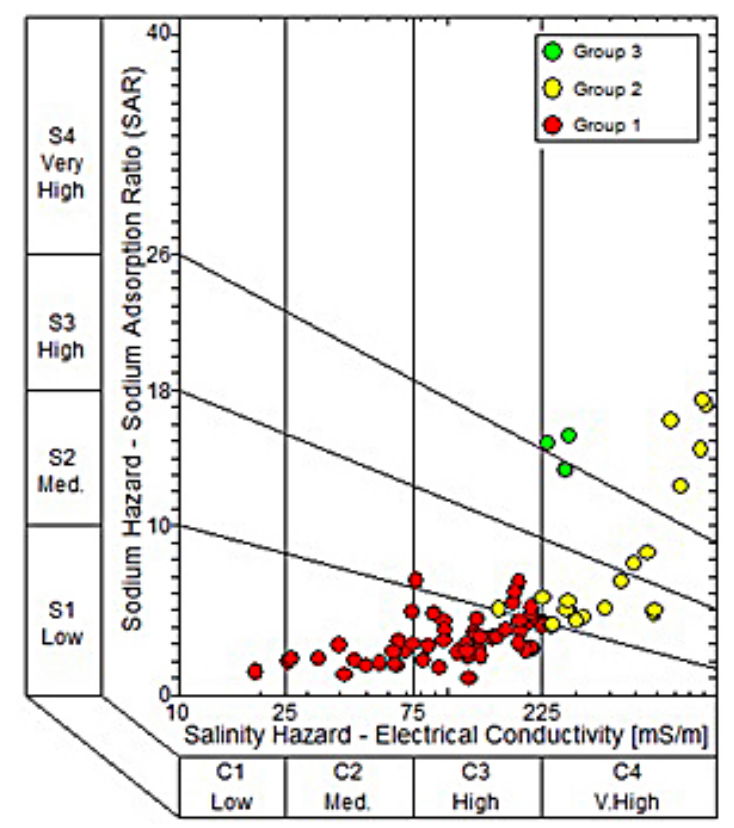

Figure 9. SAR and Salinity Hazard classification plot of groundwater samples 
Table 4. Classification of groundwater based on SAR and EC for irrigation

\begin{tabular}{|c|c|c|c|}
\hline Sodium hazard (SAR) (Class) & Water class & Number of Boreholes & \% of Boreholes \\
\hline $0-10(\mathrm{~S} 1)$ & Low & 69 & 87.3 \\
\hline $10-18(\mathrm{~S} 2)$ & Medium & 3 & 3.8 \\
\hline $18-26(\mathrm{~S} 3)$ & High & 7 & 0.9 \\
\hline$>26$ & Very High & 0 & 0 \\
\hline Salinity hazard EC (mS/m) (Class) & Water class & Number of Boreholes & 2.5 \\
\hline$<25(\mathrm{C} 1)$ & Excellent & 15 & 18.9 \\
\hline $25-75(\mathrm{C} 2)$ & Good & 38 & 48.1 \\
\hline $75-225(\mathrm{C} 3)$ & Fair & 24 & 30.4 \\
\hline$>225(\mathrm{C} 4)$ & Poor & 24 & \\
\hline
\end{tabular}

on salinity hazard (EC) is also shown in Table 4, with $70.6 \%$ of the boreholes suitable for irrigation application, and $30.4 \%$ are classified as poor and not appropriate for irrigation.

The deposits of salts in the groundwater at Leliefontein is likely due to the agricultural activities, natural groundwater movement through the geological formation and saltwater intrusion. Leliefontein is located about $100 \mathrm{~km}$ from the coast of the Northern Cape, and Kamiesberg local municipality as a whole is situated at the coastline of Northern Cape of South Africa.

\section{Water quality index}

Water quality index (WQI) is an acceptable method that offers a simplified expression of water quality for surface water and groundwater investigations. WQI is a numerical expression summarising the water quality data set into simple terms as excellent, good, poor, and unsuitable. Scientists around the world develop various WQI methods which are widely used by many authors (Amadi, 2011; Gebrehiwot et al., 2011; Desai \& Desai, 2012; Aly et al., 2014; Amaliya \& Kumar, 2015; Goher et al., 2015; Paul et al., 2015). The WQI analysis is vital to generate the maps of the groundwater quality coverage over regions of interest. WQI can be used to identify the factors and sources influencing the groundwater quality for both management of water resources and monitoring of the groundwater quality. The classification of groundwater at Leliefontein based on WQI calculations is presented in Table 5. On the basis of the cluster analysis, group 1 of 57 samples shows 15 boreholes $(26.3 \%)$ with excellent WQI, 14 boreholes $(22.8 \%)$ with good WQI, 13 boreholes $(24.6 \%)$ with poor WQI, 12 boreholes $(21.1 \%)$ with very poor WQI, and three boreholes (5.3\%) of unsuitable WQI. The group 2 groundwater 19 samples portray only one borehole $(5.3 \%)$ with excellent WQI, five boreholes (26.3\%) with poor WQI, five boreholes (26.3\%) with very poor WQI, and eight boreholes (42.1\%) with unsuitable WQI. The group 3 groundwater samples are made up of three boreholes, with one (15\%) being poor and two $(75 \%)$ very poor for WQI. The groups are in the order of Group $1<$ Group $2<$ Group 3 for WQI.

\section{Water quality spatial distribution maps}

Spatial distribution maps of WQI, $\mathrm{Na}, \mathrm{Cl}$, EC and SAR were generated for Kamiesberg local municipality by Inverse Distance Weighing (IDW) interpolation method with ArcGIS 10.8 (ESRI, 2019), are presented in Figures 10, 11, and 12. The spatial interpolation from all generated maps indicated the water quality for all parameters were best at the western portions of

Table 5. WQI classification of boreholes at the study location

\begin{tabular}{|c|c|c|c|}
\hline QWI Range & Classification & Number of Boreholes & \% of Borehole \\
\hline $0-25$ & Excellent & 16 & 20.3 \\
\hline $26-50$ & Good & 13 & 16.5 \\
\hline $51-75$ & Poor & 20 & 25.3 \\
\hline $76-100$ & Very Poor & 19 & 24.1 \\
\hline$>100$ & Unsuitable & 11 & 13.8 \\
\hline
\end{tabular}




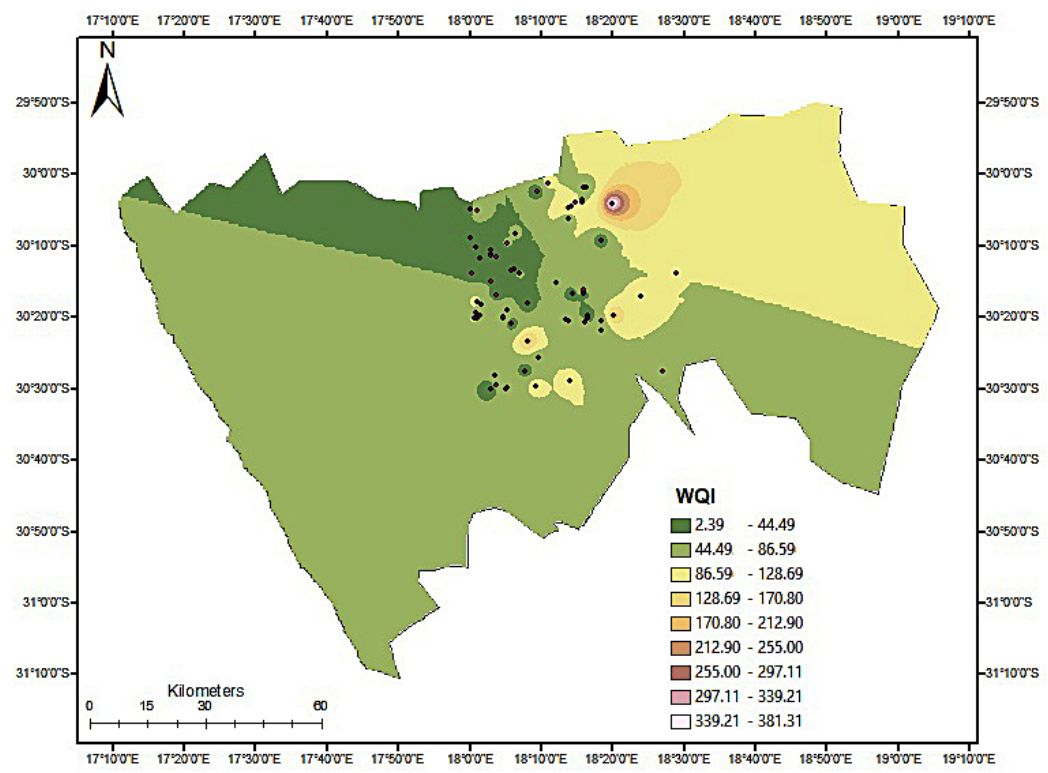

Figure 10. Spatial distribution map of groundwater for WQI in Kamiesberg
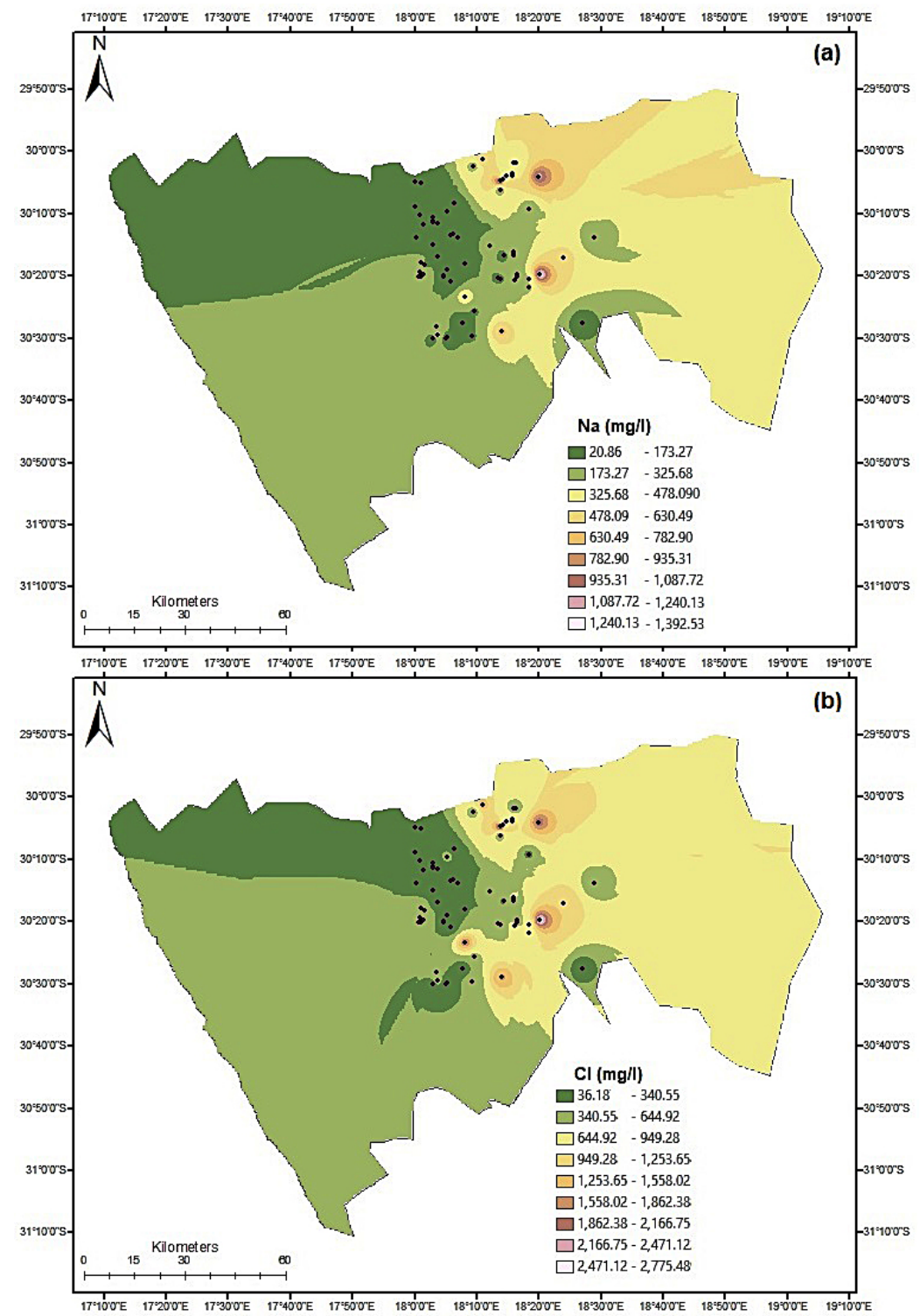

Figure 11. Spatial distribution map of groundwater for (a) $\mathrm{Na}$ and (b) $\mathrm{Cl}$ in Kamiesberg 


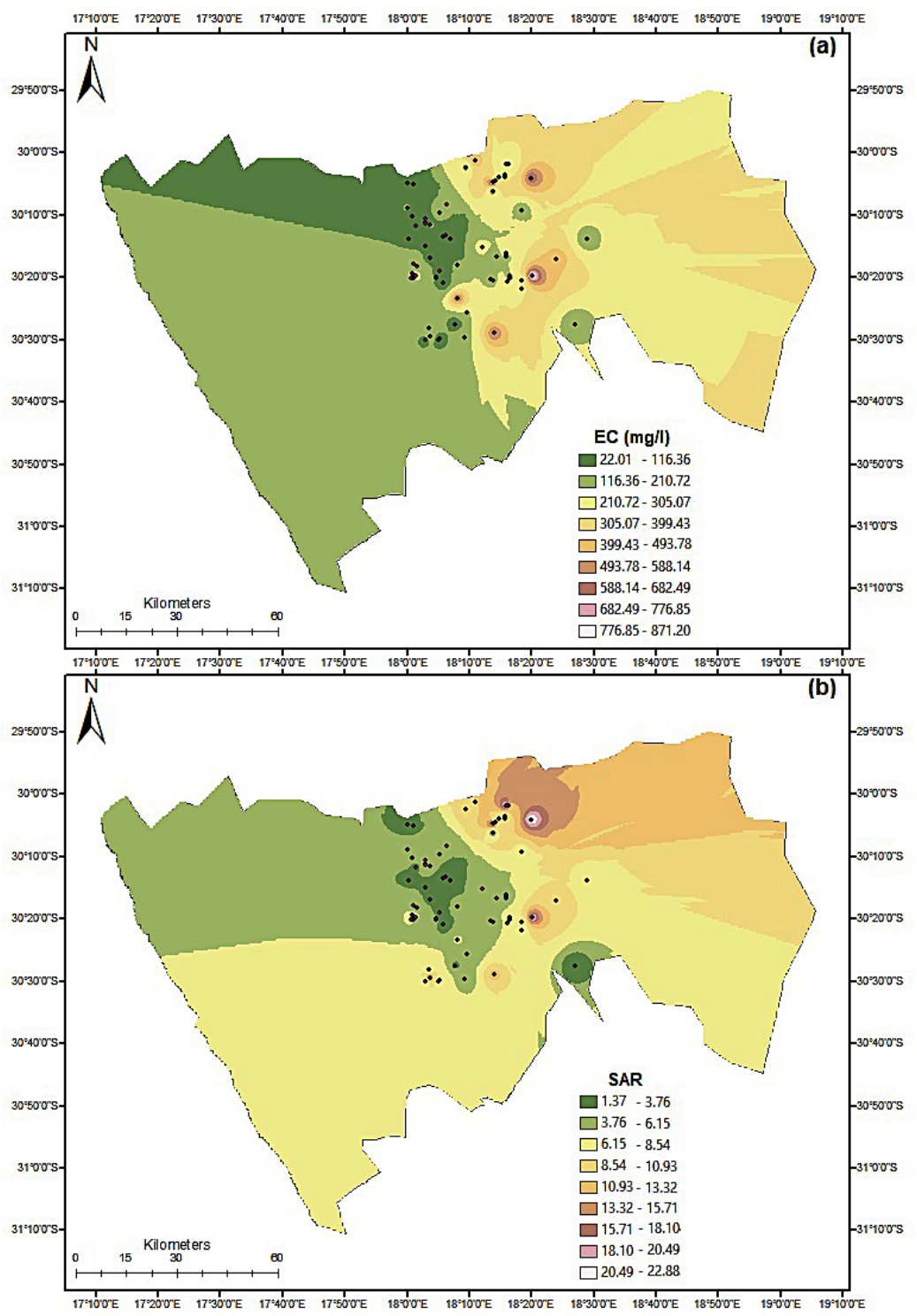

Figure 12. Spatial distribution map of groundwater for (a) EC and (b) SAR in Kamiesberg

Leliefontein, and deteriorated from the central portion towards the east. The poor groundwater quality predictions in the eastern part of Leliefontein could be as a result of ion leaching, agricultural impact, effluent discharge, geology, and anthropogenic sources.

The geology of Kamiesberg is a likely factor influencing the deteriorating groundwater quality towards the eastern portion of Kamiesberg, as shown in the geology map in Figure 3. The ECCA group geological formation located at the east part is known to exhibit high salinity in the Kalahari groundwater regions (Nell \& van Huyssteen, 2014). There are sedimentary deposits of the Ecca Group and Dwyka Formation, both of the Karoo Supergroup present at the eastern side of Kamiesberg (Figure 3). Dwyka groups at the eastern portions of Kamiesberg are known to produce the groundwater with associated with high salt concentrations of major ions (Sherman, 1998), likely contributing to the enrichment of major ion concentrations towards the eastern side of Leliefontein.

\section{CONCLUSIONS}

The groundwater quality assessment is an essential step towards groundwater management, utilisation and pollution control. The groundwater hydrochemistry data for Leliefontein was analysed for the domestic and irrigation application. Major cations, anions, EC, pH, SAR, WQI, were analysed with geostatistical and spatial modelling to predict the groundwater quality in the region. Leliefontein is dominated by $\mathrm{NaCl}$ groundwater 
type, and from the results, $94.7 \%$ indicated the $\mathrm{NaCl}$ type, $2.6 \% \mathrm{CaCl}$ type and $2.6 \% \mathrm{NaHCO}_{3}$ type. SAR and salinity hazard (EC) classifications mainly considered groundwater in Leliefontein to be suitable for irrigated agricultural activities. The water types in Leliefontein are influenced by geological interaction and anthropogenic activities. The Northern Cape is a region associated with high temperatures resulting in high evaporation rates, which potentially contributes to the high chloride content of groundwater. The groundwater is generally suitable for irrigation, but domestic consumption requires further treatment as the groundwater has high contents of chloride, sodium, and fluoride above the SANS241 (SANS, 2015) recommended guidelines. In the study area, $60-100 \%$ of the boreholes show nitrate, sodium $\mathrm{EC}, \mathrm{pH}$, and SAR within acceptable standard values prescribed by SANS241 (SANS, 2015).

This study presents an integrated approach for hydrochemical data analysis with multiple validations. On the basis of WQI, $36.8 \%$ of the samples (29 boreholes) shows an excellent to good water quality, $49.4 \%$ (39 boreholes) exhibited poor to inferior water quality, and $13.8 \%$ (11 boreholes) were unsuitable water quality for Leliefontein. SAR, EC, and major ions $\mathrm{Cl}$ and $\mathrm{Na}$ show that SAR ( $8.9 \% 7$ boreholes), EC (49.4\% 39 boreholes), $\mathrm{Cl}$ ( $57 \% 45$ boreholes), $\mathrm{Na}$ ( $45.6 \% 36$ boreholes), were above the prescribed standards, an indication of moderate level of pollution in the Leliefontein. The spatial analysis map generated for the predicted groundwater parameters show that the western portion of Leliefontein gave generally good groundwater quality, and deteriorated from the middle towards the eastern side of Leliefontein. The results show the dominance of $\mathrm{Cl}$ and $\mathrm{Na}$ as the determining factors in differentiating the different water groups and contributing to the high salinity of groundwater in Leliefontein.

\section{Acknowledgements}

The author acknowledges the support of the Institute for Groundwater Studies, University of the Free State and Mr Eelco Lukas for making WISH software available.

\section{REFERENCES}

1. Adams, S., Titus, R, \& Xu, Y. 2004. Groundwater recharge assessment of the basement aquifers of central Namaqualand. WRC Report No. 1093/1/04.
2. Aly, A.A., Al-Omran, A.M., \& Alharby, M.M. 2014. The water quality index and hydrochemical characterisation of groundwater resources in Hafar Albatin, Saudi Arabia. Arab Journal of Geoscience. https://doi.org/10.1007/s12517-014-1463-2

3. Amadi, AN 2011. Assessing the effects of Aladimma dumpsite on soil and groundwater using water quality index and factor analysis. Australian Journal of Basic Applied Science, 5(11), 763-770.

4. Amaliya, N.K., \& Kumar, S.P. 2015. Study on water quality status for drinking and irrigation purposes from the pond, open well and bore well water samples of four taluks of Kanyakumari district. International Journal of Multidisciplinary Research Development, 2, 495-501.

5. Ashley, R.P., \& Lloyd, J.W. 1978. An example of the uses of Facto analysis and cluster analysis in groundwater chemistry interpretation. Journal of Hydrology, 39, 355-364.

6. Atkinson, P., \& Quattrochi, D.A. 2000. Special issue on geostatistics and geospatial techniques in remote sensing. Computers \& Geosciences, 26 (4), 359.

7. Aza-Gnandji, C.D.R., Xu, Y., Raitt, L., \& Levy, J. 2013. Salinity of irrigation water in the Philippi farming area of the Cape Flats, Cape Town, South Africa. Water, 39 (2), 199-210.

8. Backman, B., Bodiš, D., \& Lahermo, P. 1998. Application of a groundwater contamination index in Finland and Slovakia. Environmental Geology, 36(12), 55-64. https://doi.org/10.1007/s002540050320

9. Bartier, P.M., \& Keller, C.P. 1996. Multivariate interpolation to incorporate thematic surface data using inverse distance weighting (IDW). Computers and Geoscience, 22, 795-799.

10. Benito, G., Rohde, R., Seely, M., Kulls, C., Dahan, O., Enzel, Y., Blanca, T., Efrat, B., Tamir, M., \& Roberts, C. 2010. Management of Alluvial Aquifers in Two Southern African Ephemeral Rivers: Implications for IWRM. Water Resource Management, 24, 641-667.

11. Bolstad, P. 2008. GIS Fundamentals, 3rd Edition. Atlas Books, Minnesota, p. 650.

12. Bredenhann, L., \& Braune, E. 2000. Policy and strategy for groundwater quality management in South Africa. Department of Water Affairs and Forestry.

13. Brus, D.J., \& Heuvelink, G.B.M. 2007. Optimisation of sample patterns for universal kriging of environmental variables. Geoderma, 138 (1-2), 86-95.

14. Chadha D.K. 1999. A proposed new diagram for geochemical classification of natural waters and interpretation of chemical data, Hydrogeology Journal, 7, 431-439.

15. Cogho, V.E., Kirchner, J., \& Morris, J.W. 1989. A National Groundwater Database for South Africa Development of the Database. WRC Report No 150/1/89. Water Research Commission, Pretoria. 
16. Cressie, NAC 1993. Statistics for Spatial Data, revised edition, John Wiley \& Sons, New York, p. 416.

17. Datta, P.S., \& Tyagi, SK 1996. Major ion chemistry of groundwater in Delhi area: Chemical weathering processes and groundwater flow regime. Journal of Geological Society of India, 47, 179-188.

18. Dawdy, D.R., \& Feth, J.It. 1967. Application of factor analysis in the study of chemistry of groundwater quality, Mojave River Valley, California, Water Resources Research, (2), 505-510.

19. Department of Water Affairs and Forestry (DWAF). 1996, South African Water Quality Guidelines for Domestic Use, (2nd ed.). Pretoria.

20. Desai, B., \& Desai, H. 2012. Assessment of water quality index for the groundwater with respect to salt water intrusion at coastal region of Surat city, Gujarat, India. Journal of Environment Research Development, 7(2), 607-621

21. Dubois, G., \& Galmarini, S. 2004. Introduction to the Spatial Interpolation Comparison (SIC). Applied GIS 1, (2), 9-11.

22. Durov, S.A. 1948. Natural waters and graphic representation of their composition: Dokl, Akad. Nauk. SSSR, 59, 87-90.

23. ESRI. 2019. (Environmental Science Research Institute). ArcGIS desktop software. ArcGIS Desktop 10.8, ESRI, Redlands, CA, USA.

24. Fetter, C.W. 1994. Applied Hydrogeology, 4th ed.; Prentice Hall: Englewood Cliffs, NJ, USA, pp. 543-591.

25. Fipps, G. 2003. Irrigation water quality standards and salinity management strategies. Texas FARMER Collection.

26. Fisher, R.S., \& Mullican, W.F.III. 1997. Hydrochemical evolution of sodium-sulfate and sodium-chloride groundwater beneath the northern Chihuahuan Desert, Trans-Pecos, Texas, USA. Hydrogeology Journal, 5, 4-16.

27. Garrels, R.M. 1967. Genesis of some groundwaters from igneous rocks, p. 405-20 In: PH.

28. Abelson edited.

29. Gebrehiwot, A.B., Tadesse, N., \& Jigar, E. 2011. Application of water quality index to assess suitability of groundwater quality for drinking purposes in Hantebet watershed, Tigray, Northern Ethiopia. Journal of Food and Agriculture Science, 1(1), 22-30.

30. Goher, M.E., Hassan, A.M., Abdel-Moniem, I. A., Fahmy, A.H., \& El-sayed, S.M. 2015. Evaluation of surface water quality and heavy metal indices of Ismailia Canal, Nile River, Egypt. Egypt Journal of Aquatic Research, 40, 225-23

31. Goovaerts, P. 1997. Geostatistics for Natural Resources Evaluation, Applied Geostatistics, Oxford University Press, New York, p.496.
32. Hengl, T., Bajat, B., Reuter, H., \& Blagojevic, D. 2008. Geostatistical modelling of topography using auxiliary maps. Computers \& Geosciences, 34: 1886-1899.

33. Hengl, T., Minasny, B., \& Gould, M.A. 2009a. Geostatistical analysis of geostatistics. Scientometrics 80, 491-514.

34. Hill, RA 1940. Geochemical patterns in Coachella Valley, OaJiif.: American Geophysics Union Transactions, 21, 46-49.

35. Hudson, R.O., \& Goldıng, D.L. 1997. Controls on groundwater chemistry in subalpine catchments in the southern interior of British Columbia, Journal of Hydrology, 201, 1-20.

36. Jonch-Clausen, T. 2004. Integrated water resources management (IWRM) and water efficiency plans by 2005: why, what and how? Global Water Partnership Stockholm.

37. Kimblin, R.T. 1995. The chemistry and origin of groundwater in Triassic sandstone and Quaternary deposits, northwest England and some UK comparisons, Journal of Hydrology, 172, 293-308.

38. Kroner, A., \& Blignault, H.J. 1976. Towards a definition of some tectonic and igneous provinces in western South Africa and southern South West Africa. Transaction of Geological Society of South Africa, 79, 232-238.

39. Kyriakidis, P.C., Shortridge, A.M., \& Goodchild, M.F. 1999. Geostatistics for conflation and accuracy assessment of Digital Elevation Models. International Journal of Geographical Information Science, 13 (7), 677-708.

40. Lam, N.S.N. 1983. Spatial interpolation methods: a review. The American Cartographer, 10, 129-149.

41. Leshomo, J.T. 2011. Investigation of hydrochemistry and uranium radioactivity in the groundwater of Namaqualand, Northern Cape, South Africa. MSc thesis, University of Witwatersrand, Johannesburg.

42. Li, P., Wu, J., \& Qian, H. 2016. Hydrogeochemical characterisation of groundwater in and around a wastewater irrigated forest in the south-eastern edge of the Tengger Desert, Northwest China. Expo. Health, 8, 331-348.

43. Lukas, E. 2012. WISH as a water management tool in opencast and underground collieries. Masters dissertation, University of the Free State, Bloemfontein.

44. Mackenzie, F.J., \& Garrells, R.H. 1965. Silicates: Reactivity with seawater. Science Journal, 150, 57-58.

45. Maya, A.L., \& Loucks, M.D. 1995. Solute and isotopic geochemistry and groundwater flow in the Central Wasatch Range, Utah. USA. Journal of Hydrology, 172, 31-59.

46. Mayback, M. 1987. Global chemical weathering of surficial rocks estimated from river dissolved loads. American Journal of Sciences, 287, 401-428. 
47. Mayo, A. L., \& Loucks, M.D.S. 1995. Solute and isotopic geochemistry and groundwater flow in the central Wasatch range Utah. Journal of Hydrology, 172(1-4), 31-59.

48. Miller, J.A. 1991. Summary of the hydrology of the southeastern coastal plain aquifer system in Mississippi, Alabama, Georgia and South Carolina, U. S. Geological Survey Professional Paper, 1410-A, pp. 33-36.

49. Mitas, L., \& Mitasova, H. 1999. Spatial interpolation. In: Longley, P., Goodchild, M.F., Maguire, D.J., \& Rhind, D.W. (Eds.), Geographical Information Systems: Principles, Techniques, Management and Applications, Vol. 1. Wiley, 481-492.

50. Myers, D.E. 1994. Spatial interpolation: an overview. Geoderma, 62, 17-28.

51. Nell, J.P., \& van Huyssteen, C.W. 2014. Geology and groundwater regions to quantify primary salinity, sodicity and alkalinity in South African soils. South African Journal of Plant and Soil, 31:3, 127135, DOI: $10.1080 / 02571862.2014 .921940$

52. Paul, J.M., Bij, A.S., George, B.M., Alex, E.C., \& Saranya, R. 2015. Studies on groundwater quality in and around Kothamangalam Taluk, Kerala, India. OSR-JMCE, 12(2 Ver. IV), 41-45.

53. Pietersen, K., Titus, R., \& Cobbing, J. 2009. Effective Groundwater Management in Namaqualand: Sustaining Supplies. Water Research Commission, Report No. TT 418/09.

54. Piper, A.M. 1944. A graphical procedure in the geochemical interpretation of water analyses, Am. Geophys., 25, 914-923.

55. Rajmohan, N., \& Elango, L. 2004. Identification and evolution of hydrogeochemical processes in the groundwater environment in an area of the Palar and Cheyyar River Basins, southern India. Environmental Geology, 46, 47-61.

56. Rogers, R.J. 1987. Geochemical comparison of groundwater in areas of New England, New York, and Pennsylvania. Groundwater, 27, 690-712.

57. Sadashivaiah, C., Ramakrishnaiah, C., \& Ranganna, G. 2008. Hydrochemical analysis and evaluation of groundwater quality in Tumkur Taluk, Karnataka State. International Journal of Environmental Research and Public Health, 5(3), 158-164.

58. Schot, P.P., \& Van der Wal, J. 1992. Human impact on regional groundwater composition through intervention in natural flow patterns and changes in land use. Journal of Hydrology, 134, 297-313.

59. Shepard, D. 1968. A two-dimensional interpolation function for irregularly-spaced data. In: Blue, RBS and Rosenberg, A.M. (Eds.), Proceedings of the ACM National Conference, ACM Press, New York, pp. 517-524.
60. Sherman, H.M. 1998. Thesis: The Assessment of Groundwater Quality in Rural Communities: Two Case Studies from KwaZulu-Natal, Durban, South Africa. http://hdl.handle.net/10413/4655

61. Slabbert, M.J., Moen, H.F.G., \& Boelema, R. 1999. Die geologie van die gebied Kenhardt. Expain. Sheet 2920 Kenhardt (1:250 000), Council for Geosciences, Pretoria.

62. SSA. 2006. Statistics South Africa. Water Resource Accounts for South Africa 2006: 1995 \& 2000. Statistics South Africa, Pretoria, South Africa.

63. Stallard, R.F., \& Edmond, J.M. 1983. Geochemistry of the Amazon River-the influence of the geology and weathering environment on the dissolved load. Journal of Geophysics Research, 88, 9671-9688.

64. Stambuk-Giljanovic, N. 1999. Comparison of Dalmatian water evaluation indices. Water Environment Research, 75(5), 388-405.

65. Stiff, H.A. 1951. The interpretation of chemical water analysis by means of patterns, Journal of Petrol. Technol., 3(10), 60-62.

66. South African National Standard. 2015. (SANS241:2015): Drinking Water, Part 1, Microbial, physical, aesthetic and chemical determinants, 2nd ed. Pretoria.

67. Subba Rao, N. 2002. Geochemistry of groundwater in parts of Guntur District, Andhra Pradesh, Indian Environmental Geology, 41, 552-562.

68. Swan, A.R.H., \& Sandilands, M. 1995. Introduction to Geological Data Analysis, Blackwell, Oxford.

69. Titus, R.A., Pietersen, K.C., Williams, M.L., Adams, S., Xu, Y., Colvin, C., \& Saayman, I.C. 2002. Groundwater assessment and strategies for sustainable resource supply in arid zones-The Namaqualand case study. WRC Report, 721/1/02. Water Research Commission, Pretoria.

70. Tobler, W.R. 1970. A computer model simulation of urban growth in the Detroit region. Economic Geography, 46 (2), 234-240.

71. Usunoff, E.J., \& Guzman-Guzman, A. 1989. Multivariate analysis in hydrochemistry: an example of the use of factor and correspondence analysis. Ground Water, 27 (1), 27-34.

72. Younger, PL 2007. Groundwater in the Environment: An Introduction, Blackwell Publishing Ltd, Oxford, UK \& Malden, Massachusetts.

73. Zhou, F., Huai-Cheng, G., Yun-Shan, H., \& ChaoZhong, W. 2007. Scientometric analysis of geostatistics using multivariate methods. Scientometrics, 73, 265-279.

74. Zirco Resources (SA) Pty Ltd. 2012. Geological update on the Kamiesberg heavy minerals sands project. 